أ.د. عبدالرازق مختار محمو د \& إسلام جمال محروص فراج المجلد (4) العدد (3) 2021م

فاعلية استخدام السياقية في تنمية مهارات التعبير الكتابي الإبداعي لدى تلاميذ المرحلة الإعدادية الموهوبين لغوية الغيًا

أ.د / عبدالر ازق مختار محمود \& إسلام جمال محروص فراج 
فاعلية استخدام السياقية في تنمية مهارات التعبير الكتابي الإبداعي لدى تلاميذ المرحلة الإعدادية الموهوبين لغويًّا أ.د. عبدالرازق خختار محمود

أستاذ المناهج وطرق تدريس اللغة العربية والتربية الاسلامية، كلية التربية، جامعة أسيوط، مصر Razic2005@gmail.com

$$
\text { إسلام جمال محروص فراج }
$$

ماجستير مناهج وطرق تدريس اللغة العربية، كلية التربية، جامعة أسيوط، مصر teachereslam111@gmail.com

$$
\text { قبلت للنشر في } 6 \text { / } 6 \text { / 2021م }
$$

\section{قدمت للنشر في 25/ 2021م}

ملخص: هدف البحث الحلاي إلى تنمية مهارات التعبير الكتابي الإبداعي لدئ تلاميذ المرحلة الإعدادية (الصف الأول الإعدادي) الموهو بين لغويًّا، من خلال إستراتيجية مقتر حة قائمة علن السياقية، ولتحقيق هدف البحث اتبع الباحثان كل من: المنهج الوصفي، والمنهج التجريبي ذي المجموعة الواحدة، وتكونت مجموعة البحث من تلاميذ الصف الأول الإعدادي الموهوبين لغويًّا، بلغ عددهم (37) تلميذًا وتلميذة؛ حيث تم اختيارهم وفقًا لأدوات التعرف والكشف عن التلاميذ الموهوبين لغويًا المحددة بالبحث الحلالي. وقد قام الباحثان بإعداد قائمة بخصائص التلاميذ الموهو بين لغويًا، وأخرىن بمهارات التعبير الكتابي الإبداعي المناسبة لتلاميذ الصف الأول الإعدادي الموهوبين لغويَّا، واختبار مهارات التعبير الكتابي الإبداعي لتلاميذ الصف الأول الإعدادي الموهوبين لغويًّا، وكذلك كتاب التلميذ ودليل المعلم في موضوعات التعبير الكتابي الإبداعي وفقًا للإستراتيجية المقترحة القائمة علن السياقية. وتوصل البحث إلى فاعلية الإستراتيجية المقترحة في تنمية مهارات التعبير الكتابي الإبداعي عند مستونا (الطلاقة- المرونة- الأصالة)؛ حيث جاءت الفروق دالة إحصائيًا عند مستوئ دلالة (0.01) لصالح التطبيق البعدي في اختبار التعبير الكتابي الإبداعي لتلاميذ الصف الأول الإعدادي الموهوبين لغويَّا، وكان حجم أثر الإستراتيجية كبيرًا. ويوصي البحث بإجراء المزيد من الدراسات التي تهتم بالتعبير الكتابي الإبداعي وتنمية مهار اته لدى المتعلمين. وتوظيف الإستراتيجيات الحديثة في تدريس التعبير،

\section{http://dx.doi.org/10.29009/ijres.4.3.3}


ورفع كفاءة المعلمين من خلال عقد دورات تدريبية دورية لهم حول كيفية استخدام تلك الإستراتيجيات، وبالاهتحام بمجالات التعبير الكتابي الإبداعي والتي تهم التلاميذ وتتصل بحياتهم، و تقديمها لهم بالطر ائق المناسبة، وبضرورة تضمين كتب اللغة العربية بعض موضوعات التعبير الكتبابي الإبداعي، وإعطاء حصة التعبير الاهتحام الكافي من قبل وزارة التربية والتعليم.

الكلمات المفتاحية: السياقية، تنمية مهار ات التعبير الكتبابي الإبداعي، تلاميذ المرحلة الإعدادية، التلاميذ الموهوبين لغويًّا، فاعلية 


\title{
The Effectiveness of Using Contextualism in the Development of Written Expression Skills of Preparatory Linguistically-Gifted Pupils
}

\author{
Prof. Dr. Adbel Razek Mokhtar Mahmoud \\ Professor of Curriculum\& Instruction of Arabic Language Education, College of \\ Education, Assiut University, Egypt \\ Razic2005@gmail.com \\ Eslam Gamal Mahrous Farrag \\ $\mathrm{PhD}$ researcher, Faculty of Education, Assiut University, Egypt \\ teachereslam111@gmail.com
}

Presented in 25th March 2021

Accepted in 1st June 2021

\begin{abstract}
The aim of the current research is to develop the skills of creative written expression among middle school pupils (linguistically gifted preparatory first grade pupils) through a strategy based on contextualism theory. To achieve the aim of the research, the researchers followed both the descriptive approach and the experimental one-group approach. The research group consisted of a group of linguistically gifted first-grade pupils, whose number reached (37) male and female pupils, where they were selected according to the tools of detection and identification of gifted pupils identified in the current research. The two researchers prepared a List of characteristics of linguistically gifted studentsm a list of creative writing expression skills suitable for first grade linguistically gifted preparatory pupils, and tested creative writing expression skills for first grade linguistically gifted intermediate pupils. The teacher's guide on creative expression topics was prepared according to the proposed contextualism-based strategy and the student's book on creative expression topics according to the proposed contextual-based strategy. The research concluded the effectiveness of the proposed strategy in developing creative writing expression skills at the level of (fluency - flexibility - originality). Where the differences were statistically significant at a level of significance (0.01) in favor of the post application in the test of creative writing for first-grade intermediate pupils who were linguistically gifted and the size of the impact of the strategy was large.
\end{abstract}

http://dx.doi.org/10.29009/ijres.4.3.3 
In light of the results of the current research the research recommended the following:

- Carrying out more studies concerned with creative written expression and developing his skills, as well as including the detection of language errors in creative written expression.

- Use modern strategies in teaching expression, and raise the efficiency of teachers by holding periodic courses for them on how to use these strategies.

- Attention to the areas of creative written expression that concern students, or relate to their lives, and present them to them.

- Arabic language books include some topics of creative written expression.

- Giving the share of expression adequate attention from the Ministry of Education, and explaining the importance of expression in their lives.

- Leave students free to choose topics that suit their preferences and desires under the guidance of their teachers, and provide guidance if necessary. 
خلق الله- سبحانه وتعالثى - الناس وميزهم عن بعضهم بعضًا بملكات معينة، يُطلق عليها "الموهبة الفطرية"، و التي إذا ما تم اكتشافها في وقت مبكر، وتناولها المختصون وتعهدوها بالرعاية فإنها تُصقل ويكون لها شأن كبير، أما إذا لم يتم الكشف عنها والاهتحام بها، فإنها تفنئ ويصبح صاحبها كغيره من أقرانه، ويفقد المجتمع تلك المنحة الإلهية التي قُدمت له ولم يُحسن استغلالها. ولا يخفى على أحد أن مجالات الموهبة والإبداع عند المتعلمين تتطلب جهودًا هادفةً ومنظمةً من قِبل التربويين، للعمل علن استنهاض القدرات الكامنة لدئ الموهوبين، وتحويلها إلى أداء مميز وذي لُّي فائدة للمجتمع، وفق مجال النبوغ الذي يتميز فيه الموهوب، علمئّا كان أو أدبيًّا. و الموهبة اللغوية من أهم ججالات الموهبة؛ حيث يمتاز الموهوب لغويًا بسمات وخصائص تميزه عن غيره من الموهوبين في المجالات الأخرىن، كما أنَ له حاجات ومطالب ينبغي الوفاء بها، ما يبرز

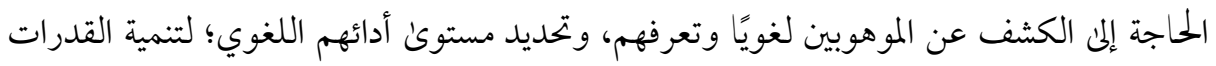
المتعددة لديهم (قاسم، 2005، 11) ويعد المتعلمون الموهوبون علئ اختـلاف مواهبهم أهم مصدر للثروة البشرية في أي مجتمع مـن المجتمعات، فلمطلب الأساس للّحاق بركب التقدم هـو رعاية الموهوبين و المبتكرين القادرين على لئل إيجاد الحلول لكثير من المشكلات التي تهدد الفـرد والمجتمع، وفئة الموهوبين فئة ذهبية وثروة قومية؛ حيث يكون من بين هؤ لاء الموهوبين صفوة العلماء و المبتكرين (الشــربيني وصــادق، 2002، 17). فيمتاز التلميذ الموهوب لغويًا بقدرة غير عادية علن حفظ المعلومات واختزانها، وبالتطور اللغوي، و كذلك بقدرة لفظية من مستوى عالِ، واستخدام التعبيرات والقياسات المجردة، والتساؤل الدائم، والتفكير المتشعب، والقدرة علن التحليل والاستدلال، وربط الخبرات السابقة باللاحقة، وأنه يستمتع بقراءة القصص وكتابة القصائد الشعرية وتحريرها (الخطيب، 2003، 251). وعند الحديث عن الإبداع والأداء اللغوي الإبداعي، يلحظ أن للغة العربية طبيعتها المتفردة؛ حيث تجد للفظ الواحد أكثر من معنى، وللمعنى أكثر من لفظ، ولكي يكون العمل الإبداعي أصيلًا في 
ثوبه، لا بد أن تكون الأفكار المنقولة في النّّ المعروض بعيدًا عن المألوف بطريقة مبتكرة توشحها

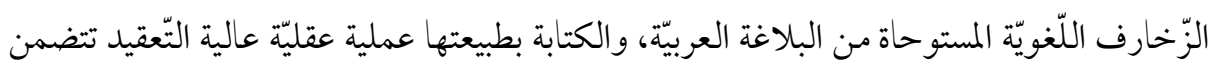

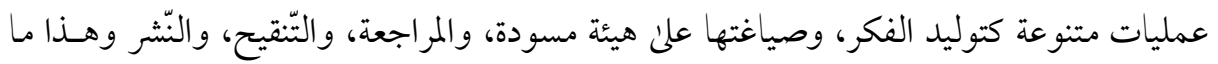

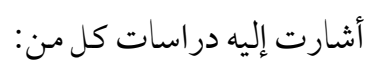
كممود(2007) والتي هدفت إلم تنمية مهارات الإبداع اللغوي من خلال برنامج تدريبي

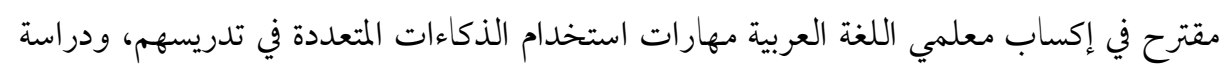
محمود وآخرين (2016) والتي استهدفت تنمية مهارات الإبداع اللغوي لدني طالبات المرحلة الثانوية

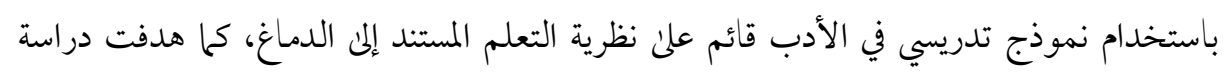
فرج(2020) والتي هدفت إلى تنمية مهارات الإبداع اللغوي لدئ تلاميذ المرحلة الابتدائية باستخدام

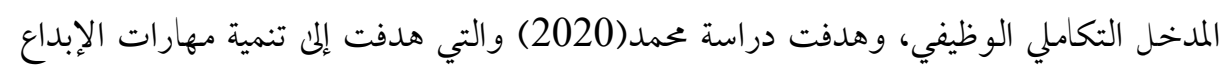
اللغوي لدئ تلاميذ الصف الأول الإعدادي باستخدام إستراتيجية سكامبر.

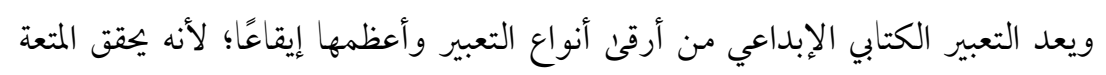

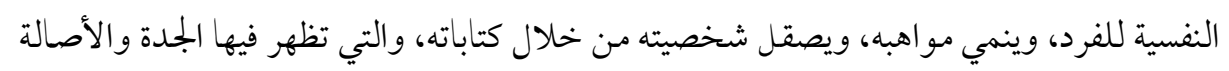

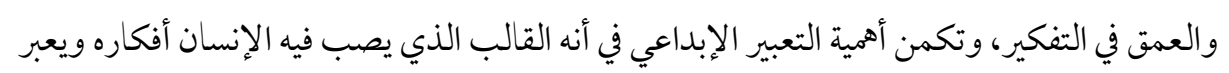

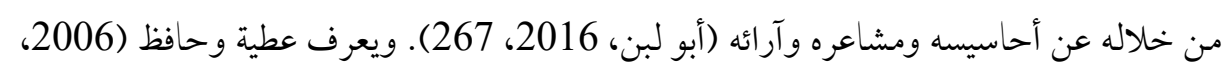

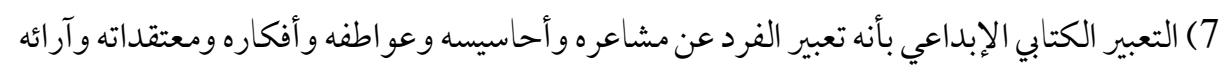

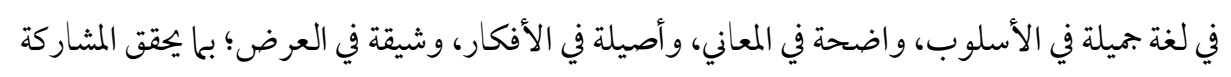
الوجدانية والقبول لدئ المتلقي. فالتعبير الكتابي الإبداعي يتيح للتلاميذ التعبير عن أفكارهم ومشاعرهم وأحاسيسهم بشكل

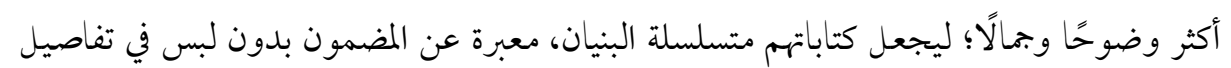
الموضوع، كما أنها تزيد من نشاط التلاميذ الكتابي وتحر رهم من القيود. 
Prof. Dr. Adbel Razek Mokhtar Mahmoud \& Eslam Gamal Mahrous Farrag

Volume (4) No. (3) 2021

وتظهر أهمية التعبير الإبداعي علن الصعيد المدرسي في نمو شخصيات التلاميذ وتكاملها،

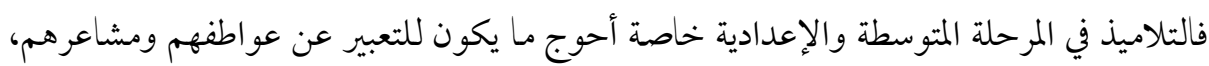

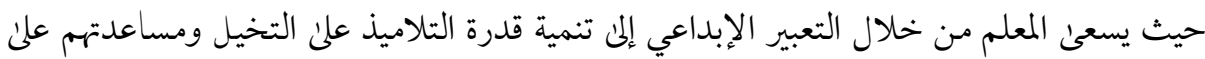

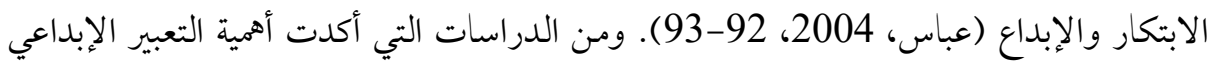

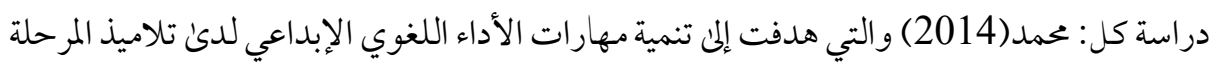

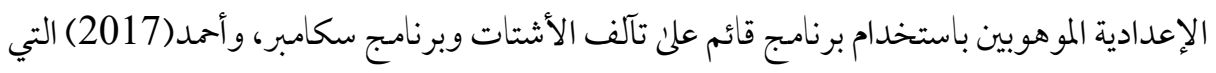

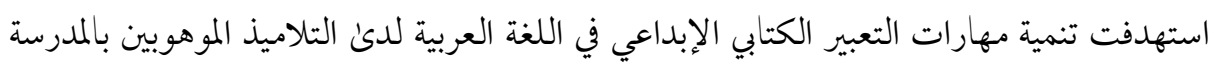

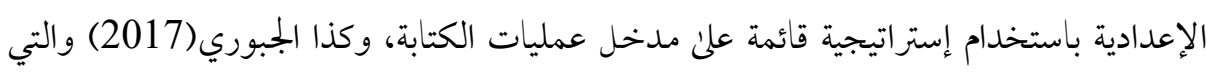

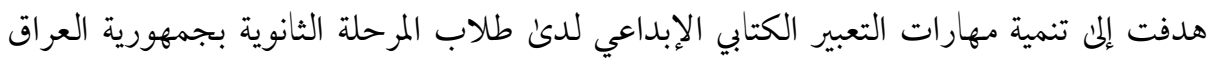

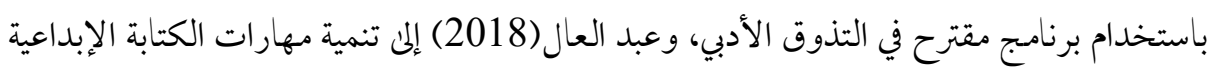
لدئ تلاميذ الصف الثاني الإعدادي عن طريق استخدام إستراتيجية التخيل الموجه.

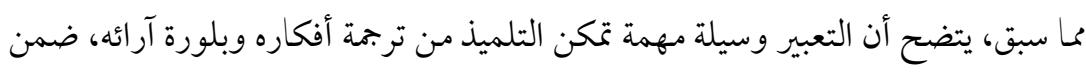

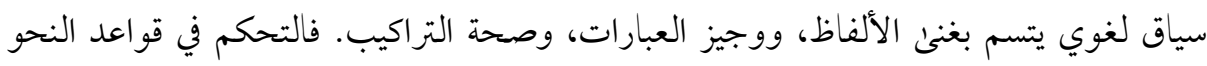

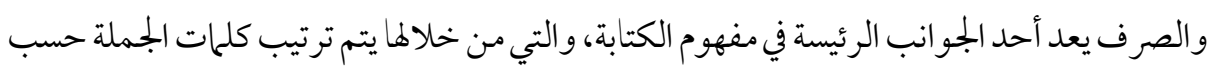
السياق الدلالي (المعني)؛ لأن هذه القواعد هي التي ترتب الكلمات حسب المبن المعنئ المقصود.

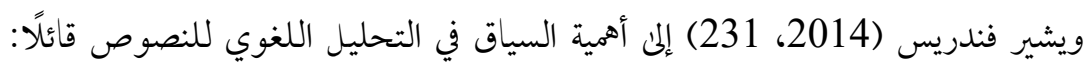

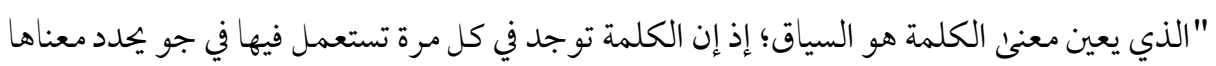

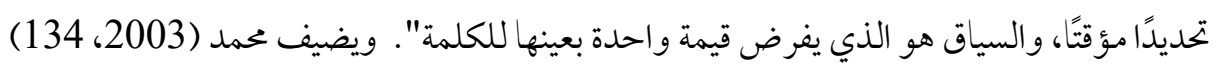

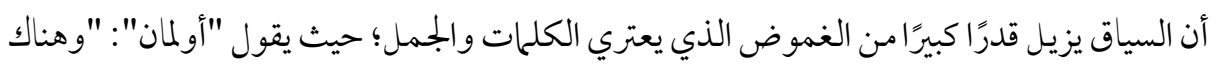

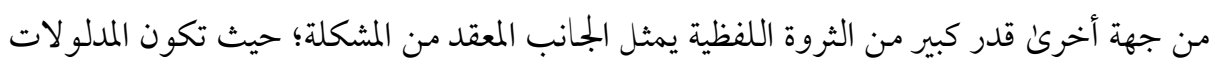
غامضة وغير محددة في أكثر الأحوال". ومن الدراسات التي تناولت السياق:

http://dx.doi.org/10.29009/ijres.4.3.3 
دراسة عبد الله (2010) والني هدفت إلى تنمية الثروة اللغوية وبعض مهارات الفهم القرائي لدئ تلاميذ الصف الخامس الابتدائي باستخدام إستراتيجية قائمة على نظرية إلماعات السياق. ودراسة ساسي (2011) والتي بينت أثر استخدام السيق في تعليمية اللغة العربية لدئ الطفل في ضوء المقاربة بالكفاءات (السنة الخامسة من التعليم الابتدائي نموذجًا). ودراسة جاب الله (2016) والتي هدفت إلى تنمية مهارات القراءة الإلكترونية لدئ متعلمي اللغة العربية للناطقين بلغات أخرى باستخدام إستراتيجية إلماعات السياق. وبالتالي، يجب علن المتعلمين إجادة كيفية الإفادة من السياق؛ حتى يتسنئ لهم الوصول إلى المعنى المراد، من خلال معرفة خصائص الكلمة ووظائفها النحوية. فالسياق يؤدي دورًا مهمًا في تزويد التلاميذ بثروة من المفردات، التي تنمي قدراتهم علن انتقاء الألفاظ والتراكيب

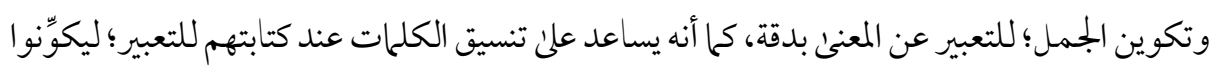
جمالاً تعبر عن المعنى المقصود. مشكلة البحث: نبعت مشكلة البحث الحلالي من خلال الشواهد التالية: - الاطلاع على نتائج الدراسات السابقة التي أكدت أهمية تنمية مهارات التعبير الكتابي بصفة عامة،

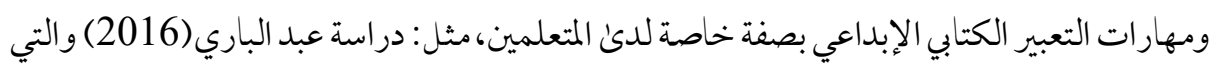
هدفت إلى تنمية مهارات التعبير الكتابي الإبداعي باستخدام برنامج قائم علنى الخرائط الذهنية، ودراسة أحمد(2017) التي استهدفت تنمية مهارات التعبير الكتابي الإبداعي لدئ التلاميذ الموهوبين بالمرحلة الإعدادية من خلال إستراتيجية قائمة علن مدخل عمليات الكتابة، ودراسة الجبوري(2017) والتي هدفت إلى تنمية مهارات التعبير الكتابي الإبداعي لدىن طلاب المرحلة الثانوية من خلال برنامج مقترح. - استشارة الخبراء والمختصين في مجال تدريس اللغة العربية: فقد تمت استشارة عدد من الخبراء والمختصين في مجال تدريس اللغة العربية بصورة عامة، وتدريس اللغة العربية بالمرحلة الإعدادية للتلاميذ الموهوبين بصفة خاصة، وقد أشاروا إلى أهمية تنمية تلك المهارات لدئ المتعلمين. 
- نتائج الدراسة الكثفية: وفي محاولة للتأكد أيضًا من الضعف في مهارات التعبير الكتابي الإبداعي لدنا التلاميذ، قام الباحثان بتطبيق اختبار في التعبير الكتابي الإبداعي علن مجموعة من تلاميذ الصف الأول الإعدادي الموهوبين لغويًّا بلغ عددهم 21 تلميذًا، وتضمن الاختبار ثلاث مهارات رئيسة (الطلاقة،

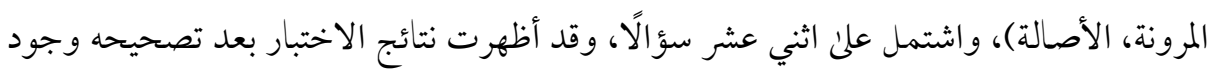
ضعف في مهارات التعبير الكتابي الإبداعي لدئ التلاميذ؛ حيث أسفرت النتائج عن وجود ضعف لدئ 76.2 ٪ من التلاميذ الموهوبين لغويًا في مهارات الطلاقة في التعبير الكتابي، و66.7٪ من التلاميذ المو هوبين لغويًا لديهم ضعف في مهار ات المرونة في التعبير الكتبابي، وكذلك 52.4 \% منهم لديهم ضعف في مهارات الأصالة في التعبير الكتابي. مما سبق تحددت مشكلة البحث الحالي في ضعف تلاميذ الصف الأول الإعدادي الموهوبين لغويًّ في بعض مهارات التعبير الكتابي الإبداعي؛ مما دعا إلى استخدام إستراتيجية قائمة علن النظرية السياقية؛ لتنمية هذه المهارات لدئ هؤلاء التلاميذ.

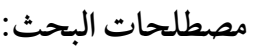
- الإستراتيجية المقترحة: تعرف إجرائيًا بأنها: بجموعة من الخطوات والإجراءات المتتابعة والمنظمة التي يتبعها التلميذ مستعينًا بالسياق في تحديد معاني الكلمات ومعرفة دلالتها، والتي من خلالها يتم مساعدة تلاميذ الصف الأول الإعدادي الموهوبين لغويًّا علن تنمية مهارات التعبير الكتابي الإبداعي لديهم؛ من خلال استخدامهم الصحيح لمعاني الكلمات، وتكوين العبارات والجمل المناسبة في المواقف المختلفة للتعبير عن أفكارهم.

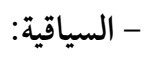
يعرفها عبد الباري (2011، 344) بأنها ما يحيط بالكلمة من نص قد يكون عبارة، أو جملة، أو فقرة، أو فصلًا كاملًا. وهناك سياق سابق ويكون قبل الكلمة الصعبة، وسياق لاحق ويكون بعد الكلمة 
ويعرفها البحث إجرائيًا بأهها: بجموعة الألفاظ، أو الكلمات، أو الجمل التي يستخدمها التلميذ في مو اقف مختلفة للتعبير عن معانٍ محددة، والتي تساعده في كتاباته؛ لتكوين عبارات وجمل مفيدة يعبر بها

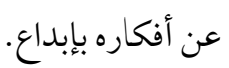
- التعبير الكتابي الإبداعي: يعرف بأنه فن أدبي نثري، يترجم فيه الكاتب حقيقة إحساسه تجاه الأشياء من حوله، ويعكس لنا فلسفة معينة في الفكر والمعتقد، من خلال الكتابة في موضوع معين، يدور حول فكرة ما، بأسلوب أدبي متميز، يكشف عن موهبة فنية في الكتابة، وسيطرة واضحة علن اللغة، وينبئ بمستقبل زاهر (حمادونصار، 2002، 27). ويعرف التعبير الكتابي الإبداعي إجرائيا بأنه مجموعة الأداءات التي تمكن تلاميذ الصف الأول الإعدادي الموهوبين لغويًا من التعبير عما بداخلهم من مشاعر وأفكار تعبيرًا واضحًا صحيحًا، باختيار الألفاظ المناسبة، مستخدمًا في ذلك مهارات الإبداع: الطلاقة، والمرونة، والأصالة، ويقاس بالدرجة التي يكصل عليها التلميذ علن اختبار التعبير الكتابي الإبداعي المعد بالبحث الحلاي.

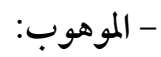

"هو المتعلم الذي يظهر أداءُمتميزًا مقارنة مع المجموعة العمرية التي ينتمى إليها في واحدة

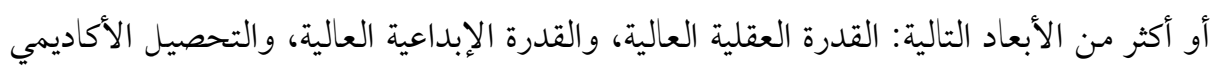
المرتفع، والقدرة على القيام بمهارات متميزة (فنية، رياضية، لغوية، والقدرة علن المثابرة والالنزام،

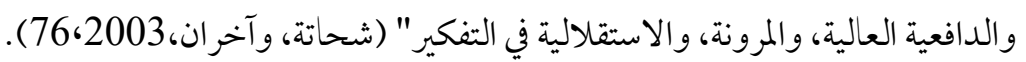

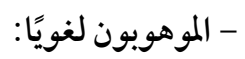
تعني الموهبة اللغوية "قدرة معرفية محددة بحدود لغوية، تستوعب جميع اللغويات من نحو، وصرف، وأصوات ولهجات، وقدرة أدبية محددة، تستوعب فروع الأدب شعرًا ونثرًا، ثم يلي ذلك قدرات خاصة بالشعر مسرحيًا، أو غنائيا، أو قصصيًا، وأخرىن خاصة بالنثر خطابًا، أو مقالًا أو رسالة أو قصة" (عصر، 2000، 69). ويعرف الموهوبون لغويًا إجرائيا بأنهم: 
Prof. Dr. Adbel Razek Mokhtar Mahmoud \& Eslam Gamal Mahrous Farrag

Volume (4) No. (3) 2021

هم تلاميذ الصف الأول الإعدادي الذين يظهرون مستويات متقدمة من التطور اللغوي، والقدرة اللفظية والكتابية التي تتسم بالطلاقة والوضوح، وعادة ما تكون حصيلتهم اللغوية متقدمة علن أقرانهم العاديين، كحا أنهم يتمتعون بمجموعة من الخصائص اللغوية والمعرفية والانفعالية التي تميزهم عن أقرانهم العاديين، ويمكن التعرُف عليهم من خلال أدوات الكشف المستخدمة في البحث الحالي. أهمية البحث:

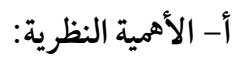

تقديم مادة علمية حول النظرية السياقية من حيث مفهومها، وأسسها، ومكوناتها، أهميتها لتنمية مهارات التعبير الكتابي الإبداعي لدىن التلاميذ، والتلاميذ الموهوبين لغويًا، وخصائصهم، وأساليب تنمية الموهبة لديهم. ب - الأهمية الميدانية: قد يفيد البحث كلًا من: 1 - تلاميذ الصف الأول الإعدادي الموهوبين لغويًّا: حيث قد يسهم البحث في تنمية بعض مهارات التعبير الكتابي الإبداعي المناسبة لديهم. 2 - معلمي اللغة العربية وموجهيها: من خلال توجيهُم إلى ضرورة الاهتمام بتعليم التعبير الكتبي الإبداعي وتنمية مهار اته لدى المتعلمين. 3 - الخبراء وخخططي ومعدي برامج اللغة العربية: وذلك بتوجيه عنايتهم إلى أهمية مهارات التعبير الكتابي الإبداعي في اللغة العربية، وأهمية استخدام إستراتيجيات تدريسية حديثة في تعليم هذه المهارات.

4 - الباحثين: حيث يفتح البحث المجال أمامهم للقيام بدراسات أخرى'، من خلال استخدام السياقية في تنمية فنون أخرىن للغة العربية، ومع فئات أخرىن من المتعلمين بالمر احل التعليمية المختلفة. أهداف البحث: هدف البحث الحلاي إلى: 1 - تحديد مهارات التعبير الكتابي الإبداعي المناسبة لتلاميذ الصف الأول الإعدادي الموهوبين لغويًّا. 
2 - تنمية بعض مهار ات التعبير الكتابي الإبداعي لدئ تلاميذ الصف الأول الإعدادي الموهوبين لغويًّا. 3- تعرف فاعلية الإستراتيجية المقترحة القائمة علن السياقية في تنمية بعض مهارات التعبير الكتابي الإبداعي لدئ تلاميذ الصف الأول الإعدادي الموهوبين لغويًّا. أسئلة البحث: سعئ البحث الحالي إلى الإجابة عن الأسئلة التالية: 1- ما خصائص تلاميذ الصف الأول الإعدادي الموهوبين لغويًا (المعرفية- الانفعالية- اللغوية)؟ 2- ما مهارات التعبير الكتابي الإبداعي المناسبة لتلاميذ الصف الأول الإعدادي الموهوبين لغويَّا؟ 3- ما الإستراتيجية المقترحة القائمة علئ النظرية السياقية لتنمية مهارات التعبير الكتابي الإبداعي لدئ تلاميذ الصف الأول الإعدادي الموهوبين لغويَّا؟ 4- ما فاعلية الإستراتيجية المقترحة القائمة علن السياقية في تنمية مهارات التعبير الكتابي الإبداعي لدنى تلاميذ الصف الأول الإعدادي الموهوبين لغويَّا؟ محددات البحث: اقتصر البحث الحلاي علن المحددات التالية: المحدد المكاني: تم تطبيق هذا البحث في مدرسة الوعاضلة الإعدادية المشتركة، إدارة صدفا التعليمية بمحافظة أسيوط. المحدد الموضوعي : الإستر اتيجية المقترحة القائمة على النظرية السياقية، وبعض مهار ات التعبير الكتبابي الإبداعي المناسبة للتلاميذ الموهوبين بالصف الأول الإعدادي، عند مستوني: (الطلاقة، والمرونة،

$$
\text { والأصالة)، بلغ عددها (14) مهارة. }
$$

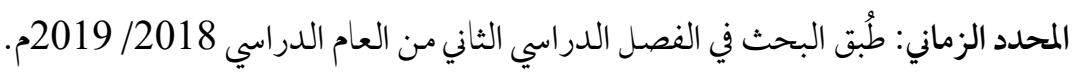
المحدد البشري: (37) تلميذًا وتلميذة من تلاميذ الصف الأول الإعدادي الموهوبين لغويَّا. منهجا البحث: في إطار التكامل المنهجي عالج الباحثان مشكلة البحث بالاعتماد على كل من المنهج الوصفي عند مر اجعة الأدبيات والدراسات السابقة وإعداد الإطار النظري للبحث، والمنهج التجريبي بالتصميم شبه التجريبي ذي المجموعة الو احدة عند تطبيق أدوات الدراسة وموادها. 


$$
\text { • قائمة خصائص التلاميذ الموهوبين لغويًّا (المعرفية- الانفعالية - اللغوية). }
$$

ه قائمة مهارات التعبير الكتابي الإبداعي المناسبة لتلاميذ الصف الأول الإعدادي الموهوبين لغويًّا.

$$
\begin{aligned}
& \text { • اختبار الذكاء العالي. (إعداد السيد محمد خيري، 1979). } \\
& \text { • اختبار التفكير الابتكاري. (إعداد أبراهام وتعريب بجدي عبد الكريم حبيب). }
\end{aligned}
$$

• كتاب التلميذ في موضوعات التعبير الكتابي الإبداعي لتـلاميـذ الصف الأول الإعدادي الموهوبين لغويًّا باستخدام إستراتيجية مقترحة قائمة علن النظرية السياقية. دليل المعلم لاستخدام إستراتيجية مقترحة قائمة علن النظرية السياقية لتنمية مهارات التعبير الكتابي

$$
\text { الإبداعي لدئ تـلاميـذ الصف الأول الإعدادي الموهوبين لغويَّا. }
$$

- اختبار مهارات التعبير الكتابي الإبداعي لتلاميذ الصف الأول الإعدادي الموهوبين لغويًّا. الإطار النظري للبحث: الموهوبون لغويًّا، والتعبير الكتابي الإبداعي، والسياقية

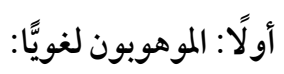

لقد مر مفهوم الموهبة عبر العقود الماضية بمجموعة من التطورات؛ فتحديد الطفل الموهوب يعتمد بشكل أساسي علن اختبارات الذكاء التقليدية والتحصيل المدرسي، ومع التطورات العلمية ونتيجة أبحاث علماء آخرين فقد تم التأكيد علن وجود عدد من العوامل الأخرىن التي في ضوئها يتم تحديد الموهوب من بين أقرانه، كما تعددت تعريفات الموهوب لغويًا بين العلماء والتربويين، كما يلي:

$$
\text { (1) تعريف الموهوب لغويًا: }
$$

يشير صادق (2001، 2) إلى أن الموهوب هو الفرد الذي يتميز عن غيره بارتفاع مستوكن الذكاء، بالإضافة إلى زيادة العوامل الدافعية والمهارية لديه، وبتبي فكرة تعدد أنواع الذكاء، يمكن الوصول إلى فكرة تعدد المواهب أيضًا، مع الأخذ في الاعتبار أن الموهوب يحتاج إلى خدمات خاصة توصلـه إلى أكـبر درجـة مـن اسـتثملار إمكاناتـه وقدر اتـه. 
ويعرف الموهوب لغويَّا بأنه (المتعلم الذي يظهر مستون مرتفعًا مـن الأداء اللغوي،

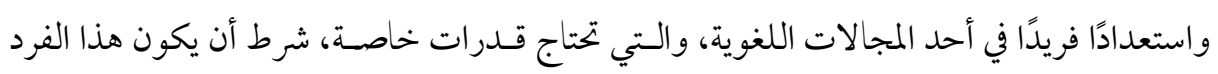

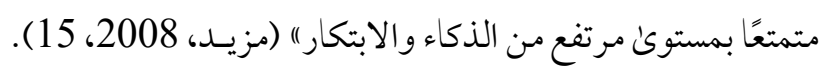

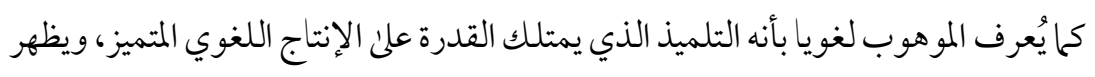

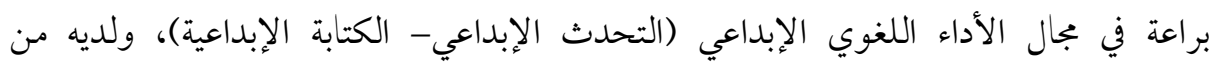

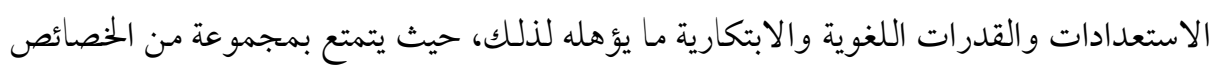

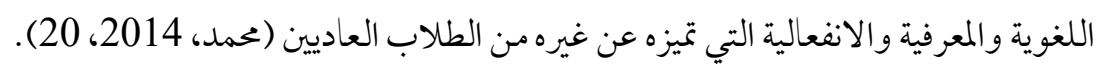

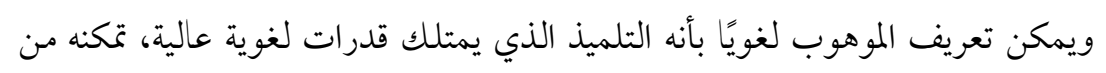

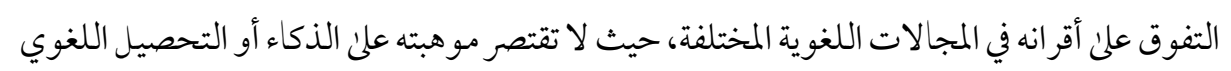
فقط، لكنه يظهر أداءً يتميز به عن بقية أقرانه بالمر حلة العمرية نفسها. (2) خصائص التلاميذ الموهويين لغويًا: هناك بمموعة من الخصائص (اللغوية، والانغعالية، والاجتماعية) التي تميز التلاميذ الموهوبين لغويًا

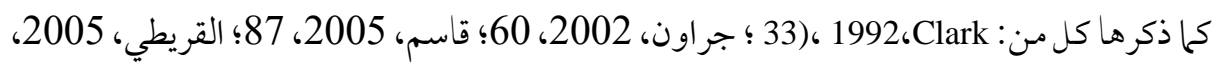

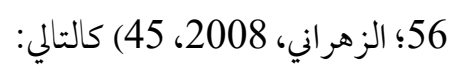
أبرز الخصائص اللغوية للموهوب لغويًا: يتصف تعبيره اللغوي بالطلاقة. يستخدم المفردات اللغوية بطريقة مفيدة ووظيفية. يستمتع بحفظ النصوص الشعرية وترديدها. يمتلك حصيلة لغوية مناسبة. يدّرك علاقات السبب والنتيجة. تتميز أفكاره بالجودة والأصالة. يستمتع بالقصص (رواية- قراءة- كتابة). 


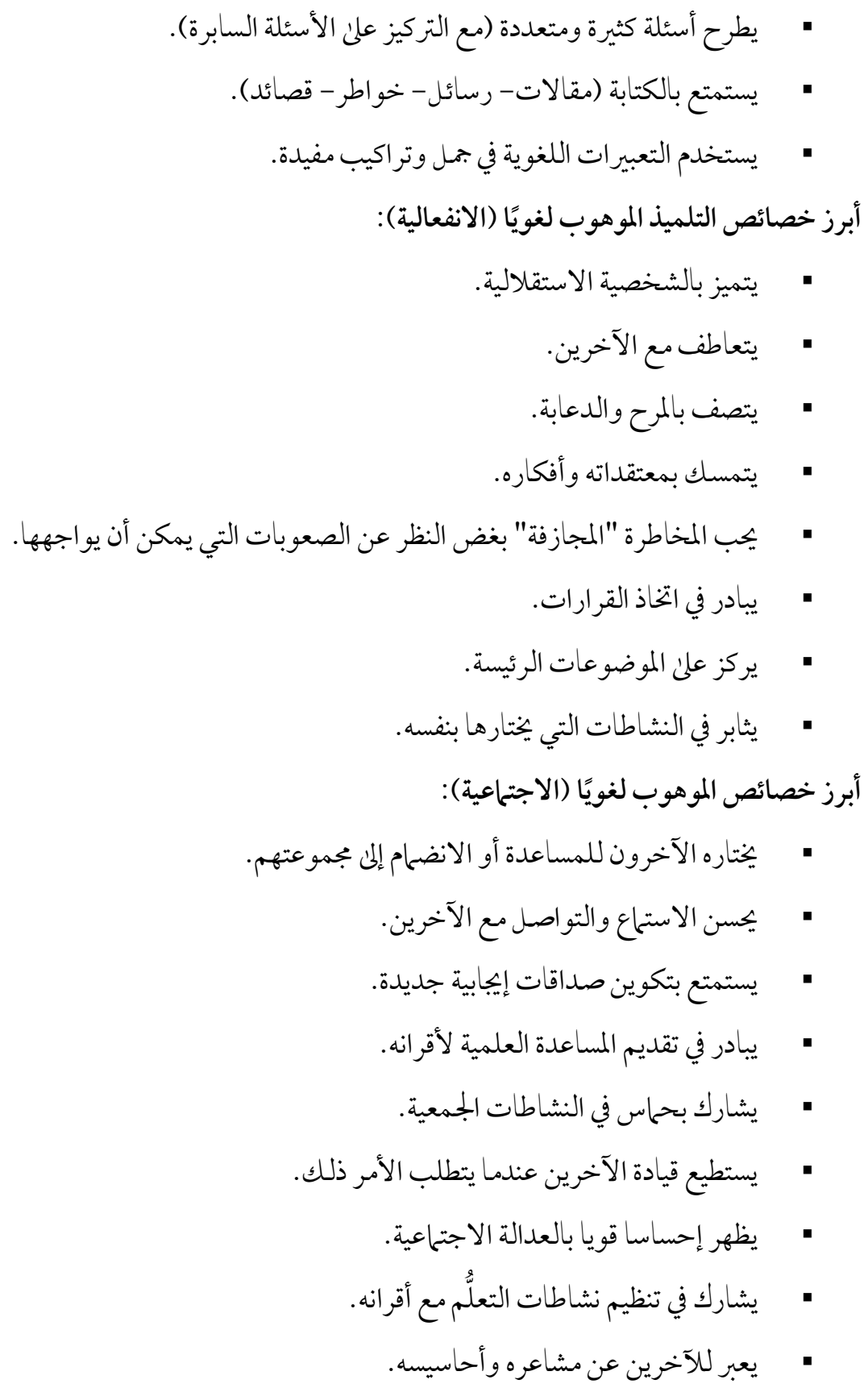


فيتسم التلاميذ الموهوبون لغويًا بقدرتهم علن التلاعب بالألفاظ شفهيًا وكتابيًا، وبحبهم للغة، ومتابعتهم الأشطة اللغوية داخل المدرسة وخارجها، وحبهم القراءة وخاصة الكتب ذات المستون الأعلى، وبقدرتهم علن الكتابة ارتجالًا. ثانيًا- التعبير الكتابي الإبداعي: الثي (1) مفهوم التعبير الكتابي الإبداعي:

يعد التعبير الكتابي أحد أنواع فنون الكتابة الذي يشمل بالإضافة إليه كلًا من الخطط والإملاء، ويعد التعبير الكتابي الإبداعي مطلبًا أساسيًا من مطالب التطور للإبداع والأصالة والطلاقة الفكرية لدئ التلاميذ. ويعرف عطية (2007، 229) التعبير الكتابي الإبداعي بأنه ذلك النوع من التعبير، الذي يقصد به إظهار المشاعر والعو اطف الجياشة والخيال المجنح، وذلك بعبارات منتقاه بدقة تتسم بالجمال، والسلاسة و القدرة علئ الإثارة وإحداث الأثر في القارئ أو السامع، أو إثارة الرغبة لديه في التعامل مع موضوعها. بينما يعرفه رشيد (2010، 20) بأنه إظهار المشاعر والإفصاح عن العواطف وخلجات النفس وترجمة الأحاسيس بعبارة منتقاة اللفظ، جيدة النسق، بليغة الصياغة، بها يتضمن صحتها لغويًا ونحويًا، وبحيث ينقل سامعها أو قارئها إلمى المشاركة الوجدانية لمن قالها أو كتبها؛ كي يعيش معه في جوه وينفعل بانفعالاته، ويجس بـا هو أحس به.

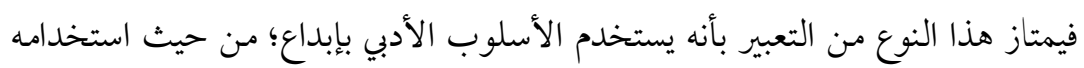

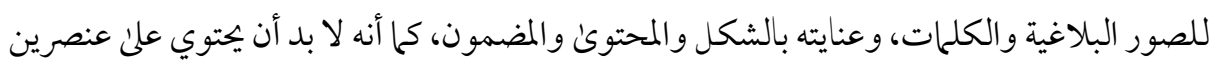
أساسيين، هما: الأصالة الفنية، والتعبير الشخصي أو الذاتي عن المشاعر والأحاسيس والأفكار. (2) مهارات التعبير الكتابي الإبداعي: من الضروري الاهتمام بتنمية مهارات الإبداع لدئ التلاميذ، وذلك حسب احتياجاتهم وقدر اتهم داخل الفصول، فمهارات الإبداع مكتسبة وقابلة للنمو والزيادة، ولعل

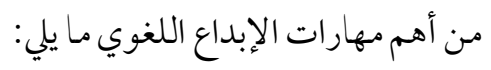


هناك تعريفات متعددة للطلاقة، فتعرف بأنها: القدرة علئ توليد عدد كبير من المترادفات، أو الأفكار، أو المشكلات، أو الاستعحالات عند الاستجابة لمثير معين، والسرعة والسهولة في توليدها. وهن في جوهرها عملية تذكر واستدعاء اختيارية لمعلومات أو خبرات أو مفاهيم سبق تعلمها (جرو ان،

وعرفها محمود (2007، 217) بأنها تعدد الأفكار الصحيحة لغويًا، التي يمكن أن يأتي بها

$$
\text { الفرد وحده في فترة زمنية معينة. }
$$

ويرئ عبد الباري (2010، 158) بأنها عدد الأفكار التي يمكن أن يأتي بها المتعلم المبدع،

وتتميز الأفكار المبدعة بملاءمتها لمقتضيات البيئة الواقعية، وبالتالي يمكن أن تستبعد الأفكار العشوائية الصادرة عن عدم معرفة أو جهل كالخرافات، وعليه كلما كان المتعلم قادرًا علن إنتاج عدد أكبر من الأفكار أو الإجابات في وحدة الزمن، توفرت فيه الطلاقة بشكل أكثر من أقرانه.

يلحظ مما سبق من تعريفات للطلاقة أنها تتطلب الوفرة والتلاؤم، فالإنسان المبدع في اللغة العربية هو الذي يمتلك ثروة من المفردات تتميز بالسهولة والسرعة والدقة في الأداء، والكثرة في إنتاج الاستجابات اللغوية المناسبة. وتتضمن الطلاقة الجحانب الكمي في الإبداع، فتتضح الطلاقة في السهولة والسرعة التي يستطيع بها المبدع استدعاء المعلومات من الذاكرة في وحدة زمنية معينة.

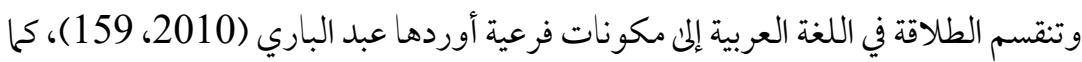

يلي: الطلاقة الفكرية، والطلاقة الترابطية، والطلاقة التعبيرية، والطلاقة اللفظية. وفي ضوء العرض السابق لمفهوم الطلاقة، وأنو اعها أو أبعادها يمكن تحديد مهار اتها الكتابية كما يلي:

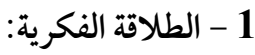

وتعني القدرة علن إنتاج عدد كبير من الأفكار في موقف معين (حبيب، 2000، 64). وعرفها فتح الباب (2016، 59) بأنها قدرة الفرد علنى أن يتتج عددًا كبيرًا من الأفكار في وقت محدد، سكا. وهذا يدل علن أن هذا الفرد في حالة تو افر الظروف يمكن أن يصبح مثل: عباس العقاد، وتوفيق الحكيم

\section{http://dx.doi.org/10.29009/ijres.4.3.3}


وغيرهما، وتظهر تلك الطلاقة في التعبير الكتابي الإبداعي من خلال قدرة المتعلم علن إنتاج أكبر عدد من الأفكار ذات الصلة الوثيقة بالمجال الإبداعي الذي يريد الكتابة فيه.

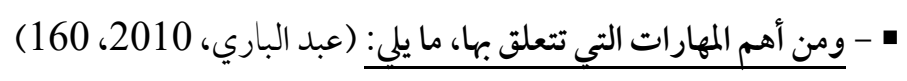
- كتابة أكبر عدد ممكن من العناوين لموضوع محدد. - توليد أكبر قدر ممكن من الأفكار عن الموضوع في فترة زمنية محددة. - كتابة أكبر عدد من المقدمات المتعددة لنهاية واحدة. - كتابة أكبر عددمن العقد القصصية لقصة لها بداية ونهاية محددة. 2 - 2 الطلاقة الترابطية: وتعني وعي الفرد بالعلاقات والسهولة التي يستطيع بها تقديم الفكرة بطريقة متكاملة المعنى

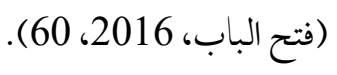

$$
\begin{aligned}
& \text { • - ومن مهاراتها ما يلي (عبد الباري، 2010، 159): } \\
& \text { - كتابة أكبر عددمن الكلمات التي تدل على لفظ معين (المترادفات). } \\
& \text { - كتابة أكبر عدد من الكلمات التي تعبر عن أكثر من معنى (المشترك اللفظي). } \\
& \text { - كتابة أكبر عدد من الكلمات التي تعبر عن عكس الكلمة (المتضادات). } \\
& \text { - ربط بين الكلمة ومدلو لات أخرى ذات علاقة بها. } \\
& \text { - يصنف الكلمات في فئات متعددة. }
\end{aligned}
$$

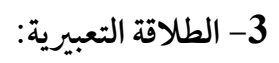

وتعني قدرة المتعلم على ترجمة الأفكار التي قام بإنتاجها في أكبر عدد من الجمل والعبارات،

التي ترتب بطريقة وثيقة بالمعنى المراد التعبير عنه، ولا يمكن أن يجيد المتعلم تلك القدرة إلا إذا توافر لديه مخزون لغوي واسع من كلمات وأشعار وشو اهد بليغة، تجعله يحسن استغلالها في التعبير عن المعنئ

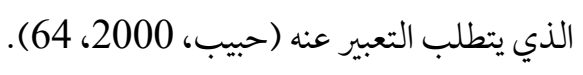

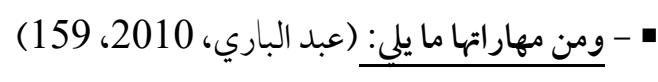




$$
\text { - - توليد أكبر عدد من الكلمات من مجموعة من الحروف. - الربط بين الجمدل؛ ليكد من الجمل من كلمات قليلة. }
$$

- الكشف عن الروابط المختلفة بين الجمل (علاقة سبب ونتيجة، عام وخاص، كل وجزء، تناقض).

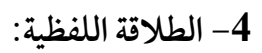

وتعني القدرة علن كتابة أكبر عدد مككن من الألفاظ، التي تتو افر فيها بعض الشروط البنائية

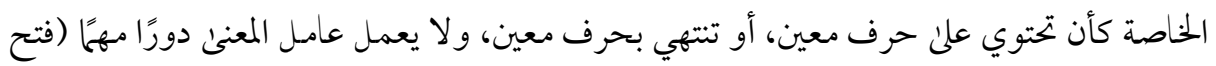
الباب، 2016، 60 20 (20)

$$
\text { - - - كتابة أكبر عدد من الكلماراتها ما يلي: (عبد الباري، التي تبدأ بحرف معين. }
$$

- كتابة أكبر عدد من الكلمات التي تبدأ بمقطع معين، وتنتهي بالمقطع نفسه. - إكمال الحروف الناقصة؛ ليولد منها كلمات ذات معني. - اشتقاق أكبر عدد ممكن من الكلمات من كلمة أو فعل. - مهارة الاشتقاق اللغوي. - مهارة استكمال الأشكال اللغوية؛ لتعبر عن أكبر عدد ممكن من الجمل.

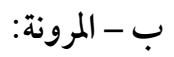

وتعني قدرة المتعلم على توليد أفكار متنوعة ليست من نوع الأفكار المتوقعة، وتوجيه أو تحويل مسار التفكير مع تغير المثير، أو متطلبات الموقف، أي درجة السهولة التي يغير بها الشخص موقفًا ما،

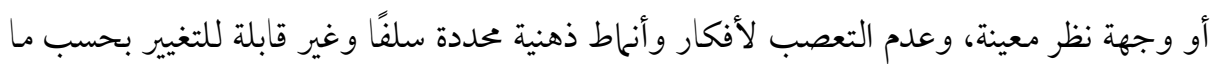
تستدعي الحاجة (أبو جبين، 2011، 68). 
يُنظر إلى الأصالة كما يرئ أبو جادو ونوفل (2007، 163) أنها مر ادفة للإبداع نفسه، ويقصد بها تلك القدرة التي تبدو في سلوك الفرد عندما يبتكر بالفعل إنتاجًا جديدًا، فالأصالة بهذا المعنى تعني الجلدة أو الندرة، بيد أن هناك شرطًا آخر لا بد من توافره إلى جانب الجلدة كي يعتبر الإنتاج أصيلًا، وهو أن يكون مناسبًا للهدف أو الوظيفة التي سيؤديها العمل المبتكر، وتعرف الأصالة بأنها: القدرة علن إبداء أو توليد أفكار جديدة، وفريدة، وخلاقة. فالأصالة تختلف عن بقية القدرات الإبداعية، في كونها لا تشير إلى كمية استجابات المتعلم أو عددها بل تهتم بجدة هذه الاستجابات، أي قلة تكرارها بين الجلماعة التي ينتمي لها. (3) أهداف تدريس التعبير الكتابي في المرحلة الإعدادية:

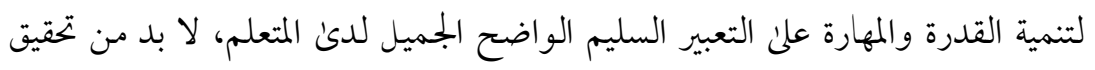

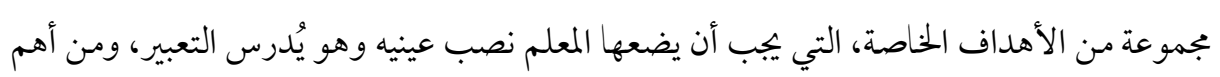
تلك الأهداف ما ذكر عاشور ومقدادي (2005، 216) أن من الأهداف التي من أجلها يُدرس التعبير ما يلي: - تمكين التلاميذ من التعبير عن حاجاتهم ومشاعرهم ومشاهداتهم وخبراتهم بعبارة سليمة صحيحة. - تزويد التلاميذ بها يحتاجونه من ألفاظ وتراكيب؛ لإضافتها إلى حصيلتهم اللغوية، واستعحالها في حديثهم. - إكساب التلميذ بجموعة من القيم و المعارف والأفكار والاتجاهات السليمة. - تعويد التلاميذ ترتيب الأفكار والتسلسل في طرحها و الربط فيا بينها، بها يضفي عليه جمالًا وقوة وتأثير في السامع والقارئ. - تهيئة التلاميذ لمواجهة المواقف الحياتية المختلفة التي تتطلب فصاحة اللسان والقدرة علن الارتجال؛ للعيش في المجتمع بفعالية. - تقوية لغة التلميذ وتنميتها وتمكينه من التعبير السليم عن خواطر نفسية شفهيًا وكتابيًا. 
- تنمية التفكير وتنشيطه وتنظيمه، و العمل على تغذية خيال التلميذ بعناصر النمو والابتكار. كما ذكر علي مدكور (2008، 257-258) أن أهداف تدريس التعبير تضمنت ما يلي: تنمية قدرة التلميذ على التعبير الإبداعي، وهذا يعني: - تنمية قدرة التلميذ علن التعبير عن الأفكار والأحاسيس والانفعالات والعواطف ومشاعر الحزن والفرح والألم، ووصف مظاهر الطبيعة، وأحوال الناس، وكتابة الشعر، والقصة، والمقالة،

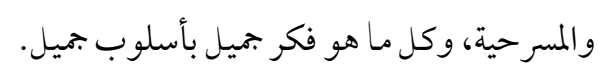

- تدريب التلاميذ علن استغلال المو اد الأخرى في التعبير. فمدرس اللغة النابه، هو الذي يحيل تلاميذه إلى موضو عات في كتب الأدب و القراءة والمو اد الاجتماعية؛ ففيها الكثير مما يمكن مناقشته، أو التعليق عليه، أو تلخيصه، وفيها ما يعين التلميذ علن الكتابة الإبداعية. كما حددت وثيقة اللغة العربية لمرحلة التعليم الأساسي (2011، 2012 ، 66-67 المئل المؤشرات والمعايير الخاصة بالكتابة والتي تمثلت فيها يلي:

$$
\begin{aligned}
& \text { - - - ميتتج المتعلم الأفكار وينظم كتابتها. } \\
& \text { - - متب المتعلم مقدمة مشوقة. } \\
& \text { - - مكتب أفكارًا جديدة متنوعة. } \\
& \text { - - مضبط الهو امش أثناء الكتابة. } \\
& \text { - - مكتب تقريرًا عن رحلة قام بها. } \\
& \text { - - يكتب رسائل عن طريق البريد الإلكتروني. }
\end{aligned}
$$

ومما سبق، يتضح أن إكساب مهارات التعبير الكتابي الإبداعي لتلاميذ الصف الأول

الإعدادي الموهوبين لغويًا بشكل خاص أمر مهم ومطلب تربوي يجب أن تسعنى إليه المؤسسات 
ثالثًا: النظرية السياقية (نظرية السياق).

1- تعريف السياقية: تعرف السياقية بأنها ما يحيط بالكلمة من نص، أو أي جزء من النص الذي يسبق أو يلي كلمة أو عبارة في النص. وقد يكون السياق عبارة عن جملة أو فقرة أو فصلٍ كاملِ. وهناك سياق

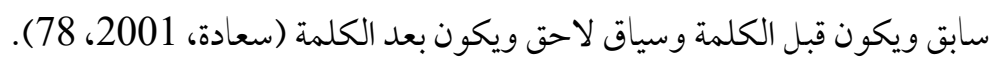
كما يمكن تعريفها بأنها: تلك الأجزاء من الخطاب التي تحف الكلمة، وتساعد في الكشف عن ون معناها، أي أنها تجسيد للتتابعات في شكل الخطاب من وحدات صوتية وصرفية ومعجمية، وما بينها من ترتيب وعلاقات تركيبية (سليمان، 2015، 49). فالسياق يؤدي دورًا مهكًا في تحديد معاني الكلمات وفهمها، وبالتالي، يستطيع تلاميذ الصف

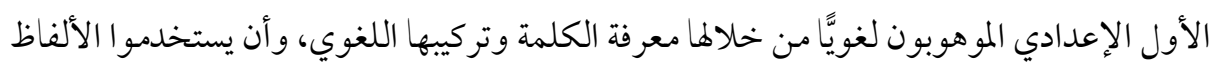
استخدامًا صحيحًا معبرًا عن المعنى المراد دون لبس أو خلل يؤدي إلى الفهم الخاطئ لمعنى الجملة ولغرضه المطلوب؛ وذلك من خلال تكوينه وترتيبه الكلمات المناسبة التي تناسب الموقف الذي ترد فيه الكلمة.

2- أهمية السياق ودوره في تحديد الدلالة وأثره في تنمية التعبير الكتابي: للسياق دور بارز في إظهار المعنى وتوضيحه، وتحاول النظرية السياقية تفسير المعنى اعتحادًا على السياق الذي ترد فيه؛ حيث تتعدد السياقات، والسياق هو الذي يخلص الكلمة من المعاني المتراكمة في ذهن الإنسان وصو لا للمعنى المقصود، وذلك من أهم مهامه. فيوضح السياق مقصود دلالة الكلمة، ويحدد معنى العبارة، وذلك من خلال المناسبة التي تحيط بالكلمة، وما يحيط بها من قرائن؛ حيث إن الكلمة الواحدة والجملة الو احدة قد تحمل مدلولين متناقضين تمامًا دون أن تختلف الكلمة في بنائها الداخلي، وإنما الذي تغير هو السياق و القر ائن المصاحبة، و أكدت ذلك دراسة كل من: عبد القادر (2002)؛ وكنوش (2007)؛ وجاب الله (2016). 
Prof. Dr. Adbel Razek Mokhtar Mahmoud \& Eslam Gamal Mahrous Farrag

Volume (4) No. (3) 2021

ولأهمية السياق؛ يرن سويرلنج (2006، s، أن استخدام إشارات السياق يُعد عاملاً مساعدًا علنّ تنمية الفهم، فالقراء غير المَهَرَة تستوقفهم الكلمات الجديدة، ويميلون إلى الاعتماد علن السياق لمعرفة معنئ الكلمات، أو اللجوء إلى التخمين لمعرفة المعنى. باستقراءما سبق، فإن عملية تعرف الكلمات من السياق تتطلب قدرات ذهنية عالية؛ حيث الثراف تتطلب استدعاء المعرفة السابقة وربطها بالمعرفة الجديدة، واستنباط معاني الكلمات، كما أن عملية

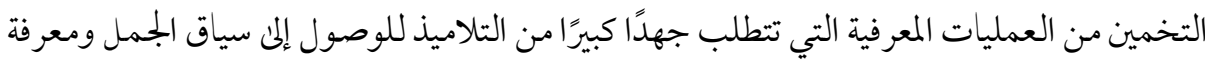
غرض الكلام الصحيح؛ تجنبًا للوقوع في الخطاً أو اللبس. 3- المبادئ والأسس التي تقوم عليها النظرية السياقية:

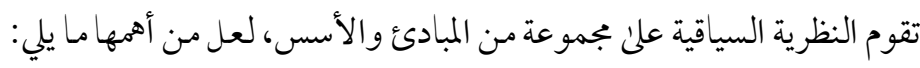
أ أ ) تأكيد دور السياق في تحديد المعني: فيتحدد معنى الكلمة من خلال السياق الذي ترد فيه؛ حيث إن للكلمة عدة معانٍ سياقية، وكل سياق

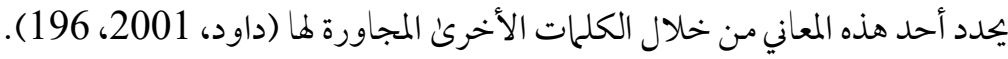
ب ) التركيز على أنواع الدلالة التي يتحدد بها المعني من خلال السياق والتي تتمثل في (الجملى، 2014، :(320 - الدلالة الصوتية: وهي التي تهتم بدراسة أصو ات الكلمات، وطر ائق نطقها، وبيان معانيها.

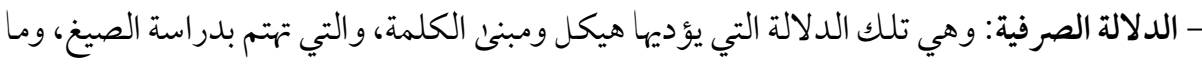

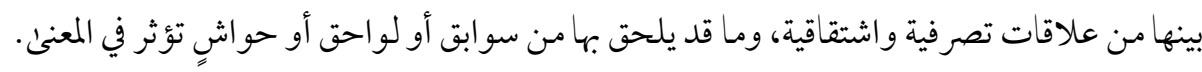

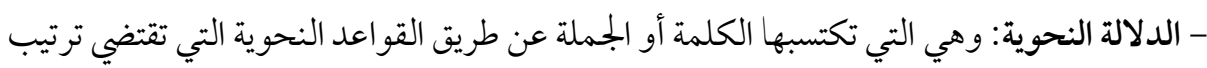

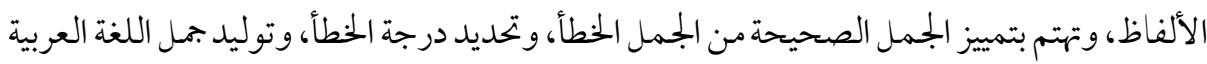
جميعها. - الدلالة المعجمية: وهي الدلالة التي وضعها السابقون للألفاظ المختلفة، وأوضحتها معاجم اللغة حسب اصطلاح المجتمع، وتستخدم في الحياة اليومية بعد تعلمها.

http://dx.doi.org/10.29009/ijres.4.3.3 
- الدلالة السياقية: وهي تلك الأجزاء التي تسبق النص، أو تليه مباشرة، ويتحدد من خلالها المعنئ المقصود، والتي يتم فيها دراسة العلاقات بين معاني الكلمات والجملم والعبارات من خلال سياقاتها التي تقع فيها. - الدلالة الوظيفية: وتعني الوظيفة التي تؤديها الكلمة. جـ ) تأكيد أدوار قرائن السياق في فهم معاني الكلمات في الموضوع: حيث يذكر السمان (2018، 30) أهم القرائن التي تعين علن الفهم، والتي تتمثل فيها يلي: - تعريف الكلمة الغامضة داخل سياق الجملة. - توضيح الكلمة الغامضة من خلال إعادة عرض معناها عن طريق كلمات أخرىن. - وصف الكلمة الغامضة الواردة في الموضوع. - مر ادف الكلمة الغامضة الواردة في الموضوع. د ) تحقيق التوازن بين أنواع السياق في فهم معاني الكلمات: حيث إن معرفة السياق ودراسة أنو اعه يعين الأفراد علن التفسير السليم للكلام وفهم الغرض منه. هـ - التركيز على تتابع عناصر السياق للوصول لفهم معاني النص: وتتمثل هذه العناصر كما ذكرها السمان (2018، 31 3) فيما يلي: - كلمات النص: وهي تمثل مفتاح النص وما فيه من معان ودلالات متنوعة، وتختلف معانيها باختلاف هيئاتها وتصريفاتها واشتقاقاتها وعلاقتها داخل الجمل في النص. - السو ابق: وهو الكلام الذي يبين معنى ما بعده، وله أهمية في بيان معاني كلمات النص؛ حيث يتحدد معنى الكلمة بالرجوع إلى ما يسبقها من كلمات تشتمل على القرائن المؤدية للمعني.

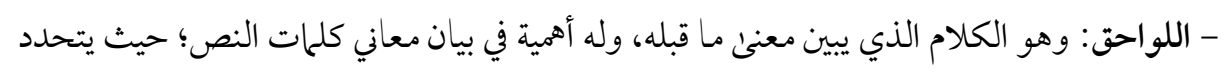
معنى الكلمة بالنظر إلى ما يلحقها من كلمات تشتمل على القرائن المؤدية للمعنىلى و - تأكيد أدوار إلماعات السياق، وإشاراته، وتلميحاته في فهم الكلمات الغامضة في النص: وتتمثل هذه الإلماعات كما ذكرها عبد القادر (2002، 166)، وعبدالله (2010، 214) فيما يلي: 


$$
\text { - - }
$$

من خلال ما سبق يتضح أن السياق يؤدي دورًا كبيرًا في تحديد معاني الكلمات وفهم معانيها، وبالتالي من خلالها يستطيع تلميذ الصف الأول الإعدادي عن طريق معرفة الكلمة وتركيبها اللغوي أن

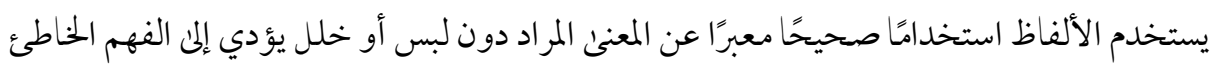
لمعنئ الجملة ولغرضه المطلوب؛ وذلك من خلال تكوينه وترتيبه الكلمات المناسبة التي تناسب الموقف

$$
\begin{array}{r}
\text { إجراءات البحث تقال فيه الكلمة. } \\
\text { إعداد أدوات البحث: }
\end{array}
$$

1- قائمة خصائص التلاميذ الموهوبين لغويًا (المعرفية- الانفعالية- اللغوية) بالمرحلة الإعدادية. أ- تحديد المدف من إعداد القائمة: تمثل الهدف من إعداد القائمة في تعرف الخصائص التي تميز التلاميذ الموهوبين لغويًا عن أقر انهم العاديين في المرحلة الإعدادية. مصادر إعداد القائمة: تمثلت مصادر إعداد القائمة في الدراسات والأدبيات السابقة التي تناولت خصائص الموهوبين بصفة عامة، والموهوبين لغويًا بصفة خاصة، ومنها، دراسة Sarouphim،(2000) ؛ أبو عوف(2004)؛ والقريطي(2005)؛ ومزيد(2008)؛ والنجلاوي(2008)؛ وقطناني 
أ.د. عبدالرازق مختار محمو د \& إسلام جمال محروص فراج المجلد (4) العدد (3) 2021م

جدول(1) نسب اتفاق المحكمين علن قائمة خصائص التلاميذ الموهو بين لغويًا في صورتها الأولية

\begin{tabular}{|c|c|c|}
\hline 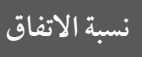 & الخصائصى الفرعية & الخصائص العامة \\
\hline$\% 96.2$ & 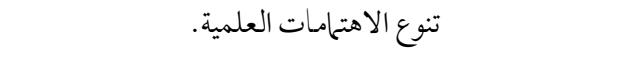 & \multirow{19}{*}{ الخصائص المعرفية } \\
\hline$\% 92.5$ & إدراك العلاقات بين الأجزاء والأفكار بصورة واضحة. & \\
\hline$\% 81.4$ & المرونة والسرعة في عمليات التفكير. & \\
\hline$\% 74.1$ & وفرة المعلومات في جميع المجالات العلمية. & \\
\hline$\% 77.7$ & 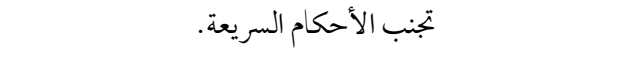 & \\
\hline$\% 85.1$ & عمق الأفكار وأصالتها. & \\
\hline$\% 81.4$ & التوصل إلن حلول غير تقليدية للمشكلات. & \\
\hline$\% 74.1$ & قدرة عالية علن التفكير المتشعب والتفكير التباعدي. & \\
\hline$\% 88.8$ & 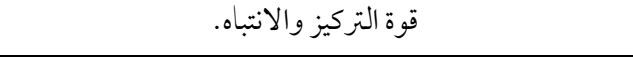 & \\
\hline$\% 85.1$ & كثرة الاطلاع. & \\
\hline$\% 96.2$ & الفضول المعرفي. & \\
\hline$\% 92.5$ & تساؤلات تفوق مستوى عمره الزمني أو الصفي. & \\
\hline$\% 81.4$ & تفضيل العمل الاستقلالي. & \\
\hline$\% 77.7$ & 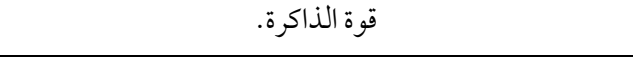 & \\
\hline$\% 85.1$ & 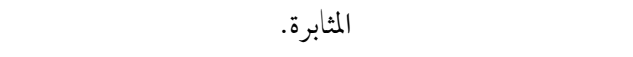 & \\
\hline$\% 81.4$ & كثرة البحث وإنشاء القو ائم والتصنيفات. & \\
\hline$\% 85.1$ & استيعاب ما يقدم إليه من مفاهيم ومعلومات بسرعة. & \\
\hline$\% 74.1$ & لديه اهتمامات بحثية ومعرفية متنوعة. & \\
\hline$\% 96.2$ & قدرات عالية في التفكير المجردو التعامل مع الأنظمة الرمزية. & \\
\hline$\% 88.8$ & الإحساس بالاختلاف عن الآخرين. & \multirow{5}{*}{ الانفعالية } \\
\hline$\% 85.1$ & القدرة علن الضبط الداخلي والتحكم بالذات. & \\
\hline$\% 96.2$ & توقع الأداء الأفضل من الذات. & \\
\hline$\% 92.5$ & السعي نحو الكمالية ومحاولة تحقيق الكمال. & \\
\hline$\% 81.4$ & حسّ الدعابة المرتفع. & \\
\hline
\end{tabular}

http://dx.doi.org/10.29009/ijres.4.3.3 
Prof. Dr. Adbel Razek Mokhtar Mahmoud \& Eslam Gamal Mahrous Farrag

Volume (4) No. (3) 2021

\begin{tabular}{|c|c|c|}
\hline 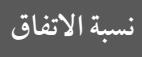 & الخصائص الفرعية & الحخصائصى العامة \\
\hline$\% 74.1$ & حساسية عالية تجاه مشاعر الآخرين. & \\
\hline$\% 96.2$ & عمق العواطف والانفعالات وقوتها. & \\
\hline$\% 92.5$ & 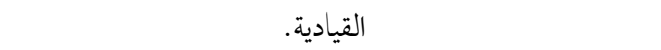 & \\
\hline$\% 81.4$ & التمسك بالقيم العليا كالعدالة والحرية والمساواة. & \\
\hline$\% 88.8$ & قوة الدافعية. & \\
\hline$\% 85.1$ & السعي إلى تحقيق الذات. & \\
\hline$\% 96.2$ & الاهتحام بمشكلات الآخرين وتقديم المساعدة لهم. & \\
\hline$\% 77.7$ & قدرة جيدة علن التمييز بين الصواب و الخطأ و الحقوق و الو اجبات. & \\
\hline$\% 81.4$ & الحساسية المفرطة والحدة الانفعالية. & \\
\hline$\% 88.8$ & الحماس في أداء المهات والاستغراق الكلان فيها. & \\
\hline$\% 85.1$ & الشعور بالمسئولية و الانضباط. & \\
\hline$\% 96.2$ & إصدار الأحكام علن الذات والآخرين. & \\
\hline$\% 96.2$ & القدرة علن التعبير الأصيل عن الأفكار. & \multirow{13}{*}{ الخصائص اللغوية } \\
\hline$\% 85.1$ & استخدام المصطلحات اللغوية بطريقة مفهومة ولما معنىل. & \\
\hline$\% 81.4$ & اتسام الأفكار اللغوية بالجدة والتفرد. & \\
\hline$\% 96.2$ & اللمسات الإبداعية اللغوية في المنطوق أو المكتوب. & \\
\hline$\% 88.8$ & قدرة عالية علن الربط بين الأشتات اللغوية لإنتاج أفكار جديدة. & \\
\hline$\% 85.1$ & التعامل مع الألغاز اللغوية بسهولة. & \\
\hline$\% 96.2$ & قدرة عالية علن استخدام التراكيب اللغوية المعقدة. & \\
\hline$\% 92.5$ & التعبير اللفظي المفصل لتفسير ما يدور حوله. & \\
\hline$\% 81.4$ & لديه حصيلة كبيرة من المفردات و المترادفات. & \\
\hline$\% 96.2$ & تكوين بناء معرفي لغوي يساعد في فهم العلاقات والمترابطات. & \\
\hline$\% 85.1$ & قدرة عالية على التفكير اللغوي المنظومي. & \\
\hline$\% 81.4$ & استيعاب المفردات اللغوية الجديدة. & \\
\hline$\% 85.1$ & إنتاج أساليب وصور لغوية جديدة. & \\
\hline
\end{tabular}

http://dx.doi.org/10.29009/ijres.4.3.3 


\begin{tabular}{|c|c|c|}
\hline 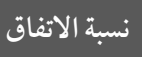 & الخصائص الفرعية & الخصائص العامة \\
\hline$\% 96.2$ & استخدام ألفاظ لغوية غير متداولة في فئته العمرية. & \\
\hline$\% 74.1$ & معدل نمو لغوي ضخم. & \\
\hline$\% 88.8$ & قدرة علن التوسع في المناقشات والمحادثات وإثر ائها. & \\
\hline$\% 85.1$ & طلاقة لغوية وفكرية. & \\
\hline$\% 96.2$ & استيعاب المقروء بسهولة. & \\
\hline$\% 77.7$ & قراءة الموضوعات التي تتطلب تفكيراً بجرداً. & \\
\hline$\% 81.4$ & خيال لغوئ خصب يتصف بالنشاط. & \\
\hline$\% .92 .5$ & التعبير الإبداعي المتميز. & \\
\hline$\% 96.2$ & تدعيم الأفكار اللغوية بالأدلة والشواهد. & \\
\hline$\% 77.7$ & استخدام الصور البيانية والمو اقف البلاغية بشكل إبداعي. & \\
\hline$\% 96.2$ & أصالة الأفكار اللغوية المطروحة. & \\
\hline$\% 85.1$ & توليد معان لغوية متعددة لفكرة واحدة. & \\
\hline$\% 81.4$ & قدرة علن ترتيب الأفكار اللغوية و اكتشاف الثغرات. & \\
\hline$\% 88.8$ & توظيف الألفاظ في سياقات لغوية ابتكارية. & \\
\hline$\% 74.1$ & قدرة لفظية وتطور لغوي مرتفع. & \\
\hline$\% 85.1$ & الميل للقراءة الحرة. & \\
\hline$\% 96.2$ & الجرأة الأدبية والقدرة الخطابية والتمثلية. & \\
\hline$\% 92.5$ & الإحساس بالجمال وتذوقه في النصوص الأدبية. & \\
\hline$\% 74.1$ & معالجة النظم اللغوية المجردة. & \\
\hline
\end{tabular}

ومريزيق(2012)، ومقابلة بعض المختصين في بجال مناهج وطرق تدريس اللغة العربية

وعلم النفس التربوي، وبعض معلمي اللغة العربية للإفادة منهم فيما يتعلق بخصائص هذه الفئة من المتعلمين.

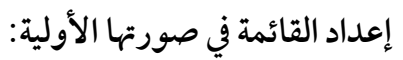


Prof. Dr. Adbel Razek Mokhtar Mahmoud \& Eslam Gamal Mahrous Farrag

Volume (4) No. (3) 2021

وتضمنت القائمة في صورتها الأولية ثلاث خصائص رئيسة، هي: الخصائص المعرفية،

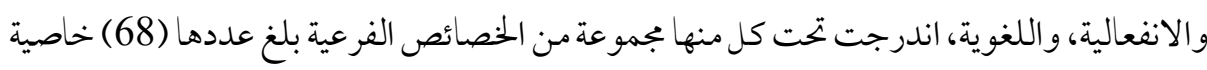
فرعية.

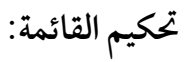
عُرضت القائمة في صورتها الأولية علن المحكمين من المختصين في مناهج وطرق تدريس

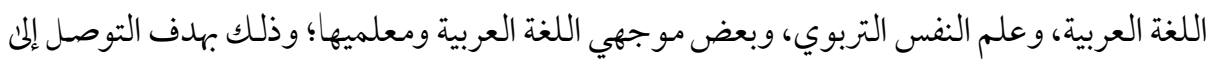

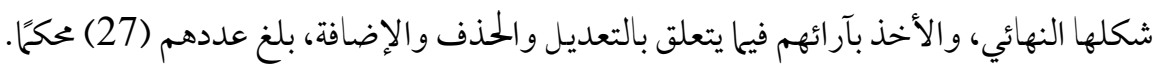
تعديل القائمة وفقا لنتائج التحكيم: بعد عرض القائمة علن المحكمين تم حساب الأوزان النسبية لنسب اتفاقهم علن الخصائص الفرعية الواردة بالقائمة، كما يتضح بالجدول التالي. وقد اتفق المحكمون علن الخصائص العامة أو الرئيسة دون تعديل أو حذف، أما في

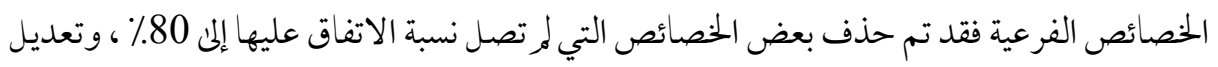
بعض الخصائص، والخصاص الفرعية التي حذفت هي: وفرة المعلومات في جميع المجالات العلمية-

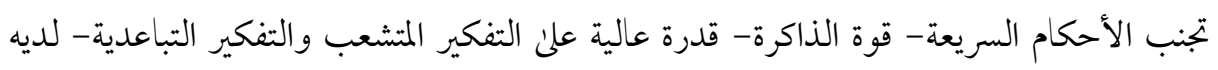

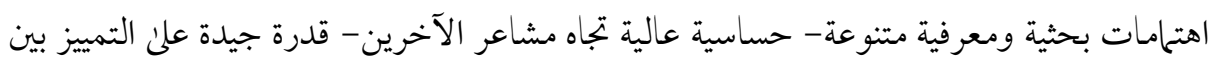

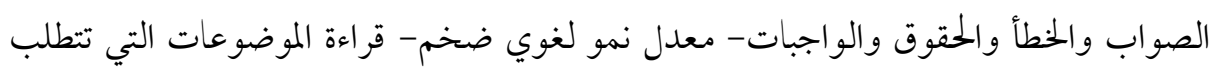

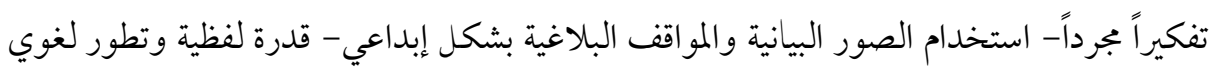
مرتفع - معالجة النظم اللغوية المجردة، قد بلغت (12) خاصية.

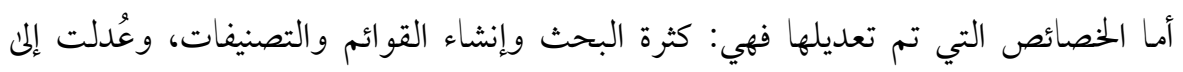

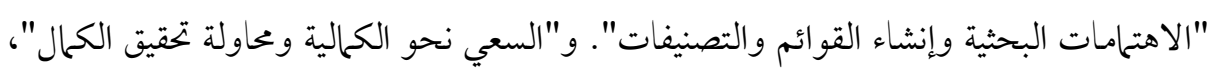

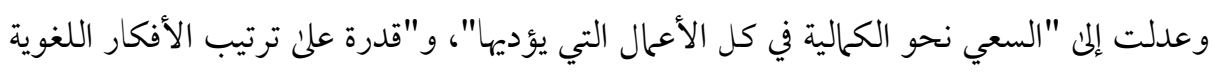

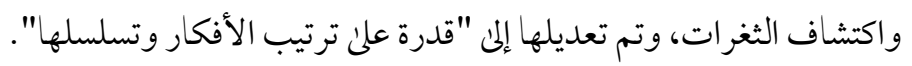

http://dx.doi.org/10.29009/ijres.4.3.3 
قائمة خصائص التلاميذ الموهوبين لغويا في شكلها النهائي:

بعد تعديل قائمة خصائص الموهوبين لغويا من تلاميذ المرحلة الإعدادية وفقال آراء المحكمين أصبحت في شكلها النهائي تحتوي علن ثلاث خصائص عامة هي: الخصائص المعرفية والخصائص الانفعالية والخصائص اللغوية، وقد اندرجت تحت كل منها بجموعة من الخصائص الفرعية تضمنت (56) خاصية فرعية، والجدول التالي يوضح الأوزان النسبية للقائمة في شكلها النهائي. جدول (2) الأوزان النسبية لخصائص التلاميذ الموهوبين لغويًا بالمرحلة الإعدادية في صورتها النهائية

\begin{tabular}{|c|c|c|}
\hline الوزن النسبي & عدد الخصائصى الفرعية & الخصائصى العامة \\
\hline$\% 25$ & 14 & الخصائص المعرفية \\
\hline$\% 26.8$ & 15 & الخصائص الانفعالية \\
\hline$\% 48.2$ & 27 & الخصائص اللغوية \\
\hline$\% 100$ & 56 & مجموع \\
\hline
\end{tabular}

أ- اختبار الذكاء العالي (إعداد السيد محمد خيري، 1979)

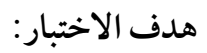

هدف اختبار السيد محمد خيري (1979) إلى قياس القدرة علن الحكم والاستنتاج من خلال ثلاثة أنواع من المواقف: مواقف لفظية، ومواقف عددية، ومواقف تتناول الأشكال المرسومة، وأستخدم الاختبار في البحث الحلالي بهدف الكشف عن التلاميذ الموهوبين لغويًا بالمرحلة الإعدادية؛ وتم اختياره من بين اختبارات الذكاء؛ لأنه يركز علن الجزء اللفظي اللغوي بصورة واضحة، وبالتالي فهو يقيس الذكاء العالي، وفي الوقت نفسه يشير إلى القدرات اللغوية المرتفعة لدني المفحوصين. وصف الاختبار:

يتكون الاختبار من (42) سؤالا، تتدرج في الصعوبة، وتتضمن عينات نختلفة من الوظائف الذهنية، أهمها: - القدرة علن تركيز الانتباه، الذي يتمثل في تنفيذ عدد من التعليات دفعة واحدة. 
- الاستعداد اللفظي، ويتمثل في التعامل بالألفاظ في أسئلة التعبير والمترادفات. - القدرة علن إدر اك العلاقات بين الأشكال، ويتمثل في المقارنة بين عدد من الأشكال للكشف عن العلاقة بينها. - الاستد لال العددي، ويتمثل في حل سلاسل الأعداد والتفكير الحسابي. - الاستدلال اللفظي، ويتمثل في الأحكام المنطقية والمتناسبات اللفظية.

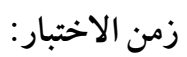

بعد إجر اء التجربة الاستطلاعية تم تحديد الزمن المخصص لإجراء الاختبار هو (30) دقيقة، بعد توزيع كراسات الاختبار وإلقاء التعليمات الخاصة به، وتوضيح كيفية الإجابة عنه. طريقة تصحيح الاختبار: يُعطى كل مفحوص درجة واحدة عن كل سؤال يجيب عنه إجابة صحيحة.

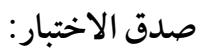

قام السيد محمد خيري (1979) بحساب صدق الاختبار بطريقتين: الأولى: حساب معامل الصدق علن أساس استخراج العلاقة بين الاختبار، واختبار الذكاء الثانوي (لإسماعيل القباني)، ووجد أنه يساوي (0.69)، والثانية: حساب معامل الارتباط بين متوسط تقدير ات المعلمين لذكاء الطالب، ودرجته علن الاختبار، وبلغ (0.64)، وهي معاملات ارتباط دالة إحصائية تشير إلى صدق الاختبار. وتم في البحث الحالي حساب صدق الاختبار من خلال: الصدق المنطقي: تم التأكد من الصدق المنطقي أو صدق المحتون عند عرض الاختبار علن المحكمين (23) محكما، حيث اتفق المحكمون علن صدق الاختبار، و ذلك بصلاحيته لقياس ماؤضع لقياسه، وأنه صالح للتطبيق على فئة التلاميذ المستهدفة. ثبات الاختبار: استخدم مُعدّ الاختبار طريقتين لحساب الثبات، الأولى: إعادة التطبيق علنى عينة مكونة من (582) طالبًا، وكان معامل الثبات يساوي (0.85)، والثانية: التجزئة النصفية، وطُبق الاختبار علئ 
عينة مكونة من (800) طالب، وكان معامل الثبات (0.88)، وهي معاملات ثبات مرتفعة، ويمكن

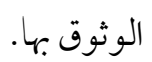

وتم حساب ثبات الاختبار في البحث الحلالي باستخدام معادلة (ألفا كرونباك)، وتعتمد هذه

الطريقة علن تطبيق الاختبار مرة واحدة، حيث طُبق الاختبار علن عينة قدرها (25) تلميذًا وتلميذة، وقد بلغ معامل الثبات بهذه الطريقة (0.84)، وبذلك يتضح أن الاختبار يتمتع بمؤشرات صدق وثبات جيدة، لذا يمكن استخدامه في البحث الحلالي، والوثوق في نتائجه.

ب- اختبار التفكير الابتكاري (إعداد أبراهام وتعريب بجدي عبد الكريم حبيب، 1990)

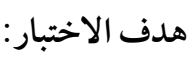

أعد "أبراهام Abraham" اختبار التفكير الابتكاري عام 1977م؛ للكشف عند درجة ابتكارية الأطفال والمر اهقين، وقد قام "بجدي عبد الكريم حبيب" (1990) بترجمة هذا الاختبار وتقنينه؛ ليكون صالحًا للتطبيق في البيئة المصرية، ويتميز هذا الاختبار بسهولة تطبيقه، ويصلح للتطبيق في جميع مراحل التعليم، ابتداءُ من مرحلة ما قبل المدرسة إلى المرحلة الجامعية، وأستخدم الاختبار في البحث الحلالي كإحدئ أدوات الكشف عن التلاميذ الموهوبين لغويًا بالمر حلة الإعدادية. وصف الاختبار: يتكون الاختبار من جزأين: الجزء الأول: تسمية الأشياء:

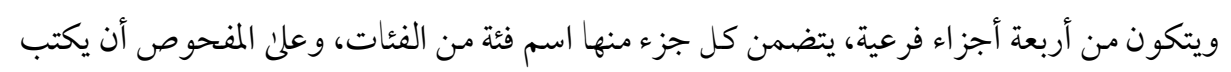
أكبر عدد ممكن من أسماء الأشياء التي تقع في هذه الفئة، ويقيس هذا الاختبار الطلاقة الفكرية، والمرونة التلقائية، والأصالة، ويُجاب عن كل جزء فرعي في (5) دقائق، ومن ثم فإن الزمن المسموح به لمجموع الأجزاء الفرعية (20) دقيقة. الجزء الثاني: الاستعملات غير المعتادة: يتكون هذا الجزء من أربعة أجزاء فرعية، ويُطلب من المفحوص في هذا الجزء أن يفكر في أكبر عدد ممكن من الاستعملات غير المعتادة لبعض الأشياء المعروفة، ويجاب عن كل جزء فرعي في (5) دقائق، ومن ثم فإن الزمن المسموح به لمجموع الأجزاء الفرعية (20) دقيقة، وتؤكد تعليات هذا 
الاختبار ضرورة أن يكون كل استعال لختلفًا عن الآخر، ويقيس هذا الاختبار الطلاقة الفكرية والمرونة التلقائية والأصالة.

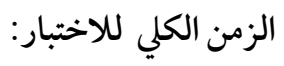

الزمن المسموح به لجميع أجزاء الاختبار هو (40) دقيقة، يُحسب منها (20) دقيقة لكل جزء من جزئي الاختبار، وتُحدد (5) دقائق لكل نقطة فرعية. تصحيح الاختبار: - n تصحح درجة الطلاقة الفكرية من خلال حصر أسماء كل الأشياء والاستعمالات التي يذكرها المفحوص بعد حذف التكرارات أو الأسماء غير المناسبة أو الغامضة لفئات الأشياء والاستعمالات التي تتضمنها بنود الاختبار. وتحدد درجة المرونة التلقائية من خلال ما يكشف عنه الفردمن تحو لات أو انتقالات من فئة إلى أخرى من فئات الاستجابة، أو علن أساس عددمرات التغيير في زاوية التفكير خلال الإجابة. أما درجة الأصالة فيُعبر عنها إحصائيا بالنسبة المئوية لتكرار الاستجابة؛ فالإجابة التي تتضمن قوة ابتكارية أصيلة ومتفردة تأخذ (درجتين)، والاستجابة التي تكون قريبة واضحة وتظهر بعض القوة الابتكارية تأخذ (درجة واحدة)، والاستجابة التي لا تعبر عن أي نوع من أنواع الأصالة تعطى صفرا. ويكشف اختبار التفكير الابتكاري عن الطلاقة والمرونة والأصالة في جزئيه: تسمية الأشياء،

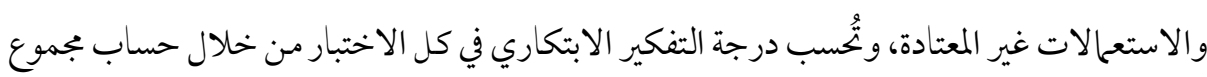
الدرجات على كل من الطلاقة، والمرونة، والأصالة. إلا أن هذا الاختبار يتأثر في تصحيحه بتقديرات المصحح، ووجهة نظره في طلاقة الإجابات، ومرونتها، وأصالتها، ومع ذلك فإنه يعطي مؤشرات قوية في الكشف عن الموهبة اللغوية، بحيث

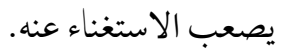




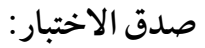

تحقق "أبر اهام" المؤلف الأصلي للاختبار من صدقه باستخدام الاتساق الداخلي له عن طريق حساب معاملات الارتباط بين الدرجات علن كل بند والدرجة الكلية للاختبار، وتراوحت قيم

$$
\text { الارتباطات بين (0.32) و(0.92). }
$$

وقام بجدي عبد الكريم حبيب بحساب صدق الاختبار باستخدام الصدق التلازمي بين

الاختبار وتقديرات المعلمين للتفكير الابتكاري لأفراد العينة ذاتها، وكان معامـل الارتباط (0.76)، ويشير ذلك إلى درجة صدق جيدة للاختبار.

وفي البحث الحالي تم حساب صدق الاختبار من خلال: الصدق المنطقي: تم التأكد من الصدق المنطقي أو صدق المحتوكن عند عرض الاختبار علن المحكمين،

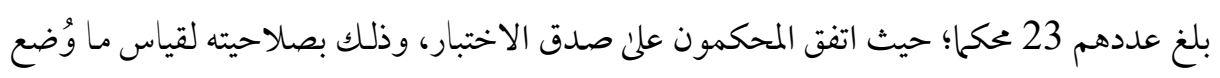
لقياسه، وأنه صالح للتطبيق على فئة التلاميذ المستهدفة.

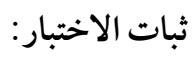

استخدم مؤلف الاختبار الأصلي (أبراهام) طريقة التجزئة النصفية لحساب ثبات الاختبار

بالاستعانة بمعادلة (سبيرمان - براون)، وقد تراوحت قيم معاملات الثبات بين (0.64) و (0.90)، للطلاقة والمرونة و الأصالة. أما بجدي عبد الكريم حبيب (1990)، فقد استخدم لحساب الثبات طريقة إعادة الاختبار وتر اوحت قيم معاملات الثبات بين (0.61) و (0.79) للطلاقة والمرونة والأصالة.

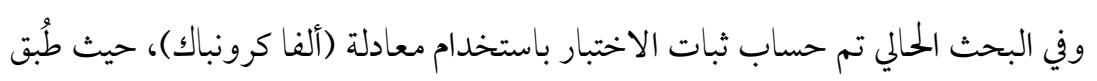
الاختبار علن عينة قدرها (25) تلميذًا وتلميذة، بو اقع فصلين من فصول الصف الأول الإعدادي، وقد بلغ معامل الثبات بهذه الطريقة (0.81)، وبذلك يتضح أن الاختبار يتمتع بمؤشرات صدق وثبات جيدة، لذا يمكن استخدامه في البحث الحلالي. 
Prof. Dr. Adbel Razek Mokhtar Mahmoud \& Eslam Gamal Mahrous Farrag

Volume (4) No. (3) 2021

3- قائمة مهارات التعبير الكتابي الإبداعي المناسبة لتلاميذ الصف الأول الإعدادي الموهوبين لغويًّا. تطلب البحث إعداد قائمة بمهارات التعبير الكتابي الإبداعي المناسبة لتلاميذ الصف الأول

$$
\text { الإعدادي الموهوبين لغويًا، وقد تم إعدادها وفقًا للخطو ات التالية: }
$$

1 - تحديد المدف من القائمة: وهو تعرف مهارات التعبير الكتابي الإبداعي المناسبة لتلاميذ الصف الأول الإعدادي الموهوبين لغويَّا؛ تمهيدًا لاستخدامها في إعداد اختبار التعبير الكتابي الإبداعي. 2 - مصادر بناء القائمة: اعتمد الباحثان عند إعداد قائمة مهار ات التعبير الكتابي الإبداعي علن: • الدراسات و البحوث السابقة المرتبطة بالتعبير الكتابي الإبداعي، ومن هذه الدراسات دراسة كل من: مدكور(2008)؛ عاصي(2012)؛ عبد الباري(2016)؛ شحاتة(2016)؛ مصلح(2017)، أحمد(2017). • أهداف تدريس التعبير في المرحلة الإعدادية، كما حددتها وزارة التربية والتعليم. " مقابلة بعض المختصين في بجال المناهج وطرق تدريس اللغة العربية، وبعض المعلمين. 3 - إعداد القائمة في صورتها الأولية: تم حصر مجموعة من مهارات التعبير الكتابي الإبداعي المناسبة لتلاميذ الصف الأول الإعدادي الموهوبين لغويًّا وتصنيفها إلى ثلاث مهارات رئيسة، هي: الطلاقة، الأصالة، المرونة، وبلغت المهارات الفرعية من المحاور الثلاث ثثاني عشرة مهارة فرعية. 4- تحكيم القائمة: تمَّ عرض القائمة في صورتها الأولية على (29) عُحكًَا من المختصين في المناهج وطرق تدريس اللغة العربية، واللغة العربية وآدابها؛ وذلك للأخذ بآرائهم فيما يتعلق بوضوح العبار ات علميا، ولغويا، والتعديل، أو الحذف، أو الإضافة، ومناسبة المهارات لتلاميذ الصف الأول الإعدادي الموهوبين لغويًّا، وكانت نسب اتفاق المحكمين علن القائمة كما يلي: جدول (3) نسب اتفاق المحكمين علن مهارات التعبير الكتابي الإبداعي في الصورة الأولية للقائمة

\begin{tabular}{|c|c|c|}
\hline 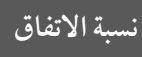 & 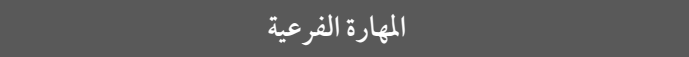 & المهارة الرئيسة \\
\hline$\% 89.6$ & كتابة أكبر عدد من الأفكار المرتبطة بالموضوع. & \multirow{2}{*}{ الطلاقة } \\
\hline$\% 100$ & يقترح أكبر عدد ممكن من النهايات لعمل أدبي: قصة، خاطرة، مقال & \\
\hline
\end{tabular}




\begin{tabular}{|c|c|c|}
\hline 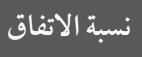 & 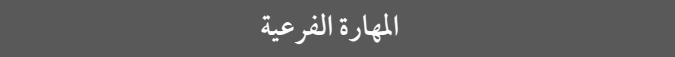 & المهارة الرئيسة \\
\hline$\% 82.7$ & يستخدم أكبر عدد من الأساليب الأدبية والبلاغية. & \\
\hline$\% 89.6$ & كتابة أكبر عدد مككن من العناوين الرئيسية. & \\
\hline$\% 100$ & كتابة أكبر عدد مككن من التعبيرات ذات المعنى عن موقف معين. & \\
\hline$\% 100$ & كتابة أكبر عدد ممكن من الجمل و العبارات عن كل فكرة رئيسة. & \\
\hline$\% 68.9$ & اقتراح مزيد من التفاصيل عن النص لإثراء الفكرة. & \\
\hline$\% 68.9$ & استخدام المفردات الجديدة وتوظيفها في الموضوع. & \\
\hline$\% 89.6$ & كتابة أسئلة متنوعة حول موضوع مـا.. & \multirow{5}{*}{ 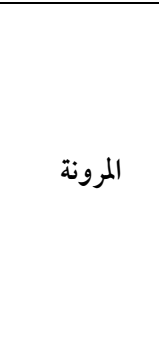 } \\
\hline$\% 86.2$ & كتابة مقدمات متنوعة تصلح لأن يبدأ بها أحد موضوعات التعبير. & \\
\hline$\% 89.6$ & كتابة أكبر عدد من الحلول المختلفة لمشكلة يعرضها في أثناء الكتابة. & \\
\hline$\% 100$ & إعادة كتابة النص بأسلوب أدبي آخر. & \\
\hline$\% 72.4$ & توظيف الشو اهد والاقتباسات & \\
\hline$\% 89.6$ & تأليف قصة قصيرة معتمدًا علان صورة مقدمة له & \multirow{5}{*}{ 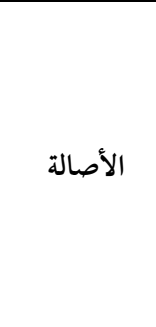 } \\
\hline$\% 100$ & كتابة نتائج مترتبة علن حدث مـا. & \\
\hline$\% 86.2$ & كتابة أفكارًا جديدة ومبتكرة حول موضوع معين. & \\
\hline$\% 86.2$ & توظيف معنى كلمة معينة في إنتاج أكبر عدد من الجمل. & \\
\hline$\% 72.4$ & رسم الصورة الفنية المعبرة. & \\
\hline
\end{tabular}

5 - ضبط قائمة مهارات التعبير الكتابي الإبداعي: بعد عرض قائمة مهارات التعبير الكتبابي الإبداعي في صورتها الأولية علن المحكمين، تم تفريغ البيانات التي تم جمعها وحساب الأوزان النسبية بين المحكمين لكل مهارة فرعية من المهارات الرئيسة؛ وذلك للاحتكام إلى هذه النسب في استبعاد بعض لهر المهارات التي حظيت بنسب اتفاق بين المحكمين أقل من 80٪ وهو المعيار الذي اتخذه البحث كمعيار

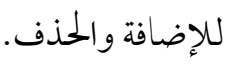
وقد اتفق المحكمون على المهارات الرئيسة دون تعديل أو حذف، أما في المهارات الفرعية فقد تم تعديل بعض المهارات، وحُذف المهارات التي لم تصل نسبة الاتفاق عليها إلى 80٪ والمهارات الفرعية التي 
Prof. Dr. Adbel Razek Mokhtar Mahmoud \& Eslam Gamal Mahrous Farrag

Volume (4) No. (3) 2021

حذفت: اقتراح مزيد من التفاصيل عن النص لإثراء الفكرة (الطلاقة)- استخدام المفردات الجلديدة وتوظيفها في الموضوع (الطلاقة)- توظيف الشو اهد والاقتباسات (المرونة)- رسم الصورة الفنية المعبرة

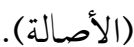

أمسا المهارات الأدائية التي تم تعديلها في قائمة مهارات التعبير الكتابي الإبداعي فهي: "يقترح أكبر

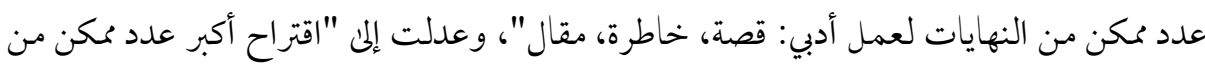
النهايات لعمل أدبي: قصة، مقال، خاطرة"، و"يستخدم أكبر عدد الأساليب الإنشائية والخبرية، وعدلت إلى "التنويع بين الأساليب الأدبية والبلاغية"

ومن ثم تم التوصل إلى الصورة النهائية لقائمة مهارات التعبير الكتابي الإبداعي المناسبة لتلاميذ الصف الأول الإعدادي الموهوبين لغويًّا، كما بالجدول التالي.

جدول (4) وصف قائمة مهارات التعبير الكتابي الإبداعي لتلاميذ الصف الأول الإعدادي الموهوبين لغويًّ في شكلها النهائي

\begin{tabular}{|c|c|c|}
\hline الوزن النسبي & عدد المهارات الفرعية & المهارات الرئيسة \\
\hline$\% 42.8$ & 6 & الطلاقة \\
\hline$\% 28.6$ & 4 & المرونة \\
\hline$\% 28.6$ & 4 & الأصالـة \\
\hline$\% 100$ & 14 & مجموع \\
\hline
\end{tabular}

بعد التوصل للصورة النهائية لقائمة التعبير الكتابي الإبداعي، بلغ عدد المهارات الرئيسة للقائمة ثلاث مهارات رئيسة هي: الطلاقة، والمرونة، والأصالة، بينما بلغ عدد المهارات الفرعية أربع عشرة مهارة فرعية، وتتفق الدراسة الحالية مع دراسة كل من: محمد(2014)؛ أبو لبن(2016)؛ عبد الباري(2016)؛ أحمد(2017)؛ عبد العال(2018).

وبذلك تمت الإجابة عن السؤال الثاني للبحث، ونصه: "ما مهارات التعبير الكتابي الإبداعي لدى

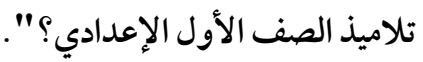




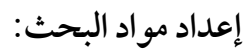

للإجابة عن السؤال الثالث من أسئلة البحث ونصه "ما الإستراتيجية المقترحة القائمة على النظرية السياقية لتنمية مهارات التعبير الكتابي الإبداعي لدئ تلاميذ الصف الأول الإعدادي الموهوبين لغويَّا؟" قام الباحثان بتصميم إستراتيجية مقترحة قائمة علني السياقية لتنمية مهارات التعبير الكتبابي الإبداعي لتلاميذ الصف الأول الإعدادي الموهوبين لغويًّا، وتشمل الإستراتيجية: الفلسفة التي تستند إليها، والهدف العام منها، وأسس بنائها، وكذلك خطو اتها، كما يلي: - الفلسفة التي تستند إليها الإستراتيجية المقترحة: النظرية السياقية لفيرث هي الأساس النظري الذي تنطلق منه الإستراتيجية المقترحة. ومن أسس هذه النظرية ما يلي: أ ) تأكيد دور السياق في تحديد المعني. ب ) التركيز علئ أنواع الدلالة التي يتحدد بها المعني من خلال السياق السياق. جـ ) تأكيد أدوار قرائن السياق في فهم معاني الكلمات في الموضوع. د ) تحقيق التوازن بين أنواع السياق في فهم معاني الكلمات. م) التركيز علن تتابع عناصر السياق للوصول لفهم معاني النص. و ) تأكيد أدوار إلماعات السياق، وإشار اته، وتلميحاته في فهم الكلمات الغامضة في النص. • الهدف العام للإستراتيجية المقترحة: هدفت الإستراتيجية المقترحة إلى تنمية مهارات التعبير الكتابي الإبداعي لدئ تلاميذ الصف الأول الإعدادي الموهوبين لغويًّا. • أسس بناء الإستراتيجية المقترحة: تم الاعتماد في بناء الإستراتيجية على ما يلي:

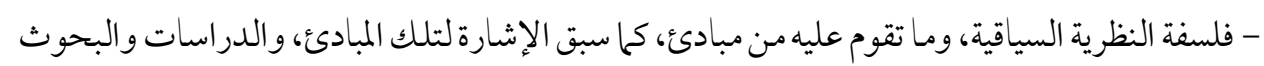
السابقة في محوري النظرية السياقية، والتعبير الكتابي الإبداعي، بالإطار النظري للبحث. - الخصائص النمائية لتلاميذ المرحلة الإعدادية الموهوبين لغويًا. - مفهوم السياق وأنو اعه، ومهار اته. - مفهوم التعبير الكتابي الإبداعي ومتطلبات تنمية مهار اته. 
- الدراسات والبحوث السابقة في مجلي السياقية، والتعبير الكتابي الإبداعي منها دراسة موسئ (2008)؛ ساسي(2011)؛ محمد(2017)؛ محمود(2017)، دميثير(2018)؛ محمد(2014)؛ ناصر(2017)؛

$$
\text { عبدالعال (2018)؛ حسين(2018)؛ علي (2018). }
$$

•- خطوات الإستراتيجية المقترحة: تتمثل خطوات الإستراتيجية المقترحة في ثلاث خطو ات، كالآتي: الخطوة الأولى: التهيئة للموضوع، وتشمل ما يلي: - يقوم المعلم بطرح أسئلة أو عرض قصة أو موقف مرتبط بالموضوع. - يناقش المعلم التلاميذ في الموضوع المقدم لهم من خلال أسئلة. الخطوة الثانية: عرض الموضوع، ويشمل الآتي: - يطلب المعلم من تلاميذه قراءة الموضوع. - يتابع ردود أفعال التلاميذ بعد القراءة. - يستجيب لأسئلة التلاميذ ويعلق على آرائهم. الخطوة الثالثة: التفكير في الموضوع وتحقق المعنى: - يوجه المعلم التلاميذ للبحث عن المعاني والدلالات المتعلقة بسياق الموضوع. - يوجه المعلم التلاميذ للبحث عن الكلمات الغامضة وغير المألوفة لديهم من خلال طرح الأسئلة التي تتناول هذه الكلمات. - يبحث التلاميذ عن الكلمات المتضادة والمتحاثلة، و كذلك العلاقات بين الجمل و الفقرات. - يوجه التلاميذ إلى تحديد المعنئ المقبول للجملة من خلال إعادة بناء السياق المناسب. وبذلك تمت الإجابة عن السؤال الثالث من أسئلة البحث. 2 - كتاب التلميذ في ضوء الإستراتيجية المقترحة: تم إعداد كتاب التلميذ الموهو ب لغويًا بالصف الأول الإعدادي لبعض موضوعات التعبير الكتابي الإبداعي في ضوء الإستراتيجية المقترحة القائمة على النظرية السياقية. 
أ - المدف من كتاب التلميذ: هدف الكتاب المعد للتلاميذ إلى تقديم محتوكن موضوعات التعبير الكتابي

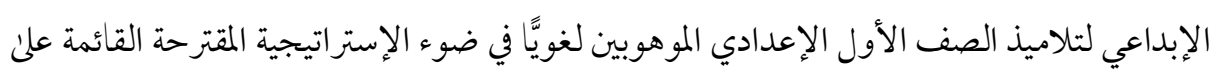
السياقية؛ وذلك لتعرف أثرها في تنمية مهارات التعبير الكتبابي لديهم. ب - مصادر بناء الكتاب: الدراسات والبحوث السابقة في مجال تدريس التعبير الكتابي الإبداعي، منها ما يلي: دراسة محمود(2007)؛ موسي(2008)؛ محد(2014)؛ ناصر(2017)؛ ساسي (2011)؛ محمود(2017)؛ دميثير(2018) . • بعض المختصين والأكاديميين في بجال تدريس اللغة العربية، وطرق تدريسها، وخبراء الميدان بلغ عددهم (17) مختصًا. • وثيقة المعايير القومية للمتعلم في مادة اللغة العربية لعام 2011/ 2012م. في ضوء هذه المصادر تم إعداد كتاب التلميذ في صورته الأولية. حيث تضمن الكتاب ستة موضوعات لتدريس التعبير الكتابي الإبداعي وهي كالتالي: الموضوع الأول سليمان والنملة، الموضوع

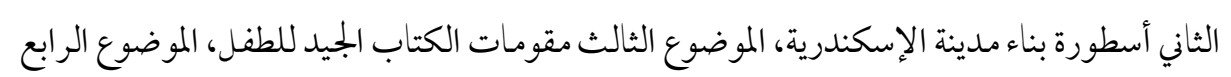
المعلم ونهضة الدولة، الموضوع الخامس حكمة من الصين، الموضوع السادس وادي النمل. جـ - عرض الكتاب على السادة المحكمين: • تم عرض كتاب التلميذ في صورته الأولية علن مجموعة من المحكمين في مجال اللغة العربية، وطرق تدريسها؛ وذلك للاسترشاد بآر ائهم في إعداد الكتاب؛ لتحقيق الفائدة المرجوة من إعداده.

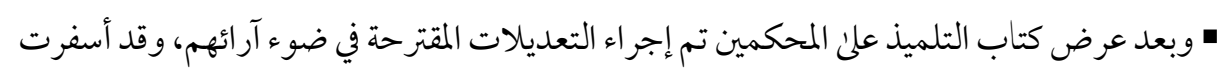

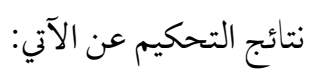
• تعديل بعض العبارات المستخدمة عند صياغة الأنشطة بالكتاب؛ نظرًا لعدم ملاعمتها للتعبير الكتابي

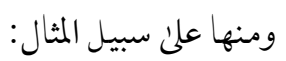


Prof. Dr. Adbel Razek Mokhtar Mahmoud \& Eslam Gamal Mahrous Farrag

Volume (4) No. (3) 2021

- بالنسبة لموضوع المعلم ونهضة الدولة (م4) تم تعديل عبارة "اكتب خاتمة مناسبة " إلى "اقترح نهاية جديدة لهذا الموضوع". وتم إجراء التعديلات اللازمة، ومن ثم تم التوصل للصورة النهائل النئية للكتاب.

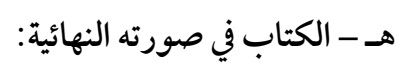
بعد عرض الكتاب في صورته الأولية؛ وذلك بهدف تحديد مدني استيفائه للمكونات

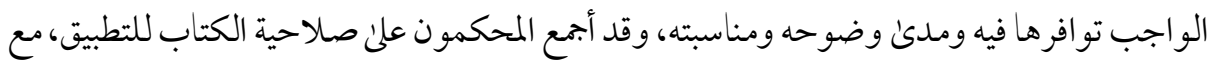

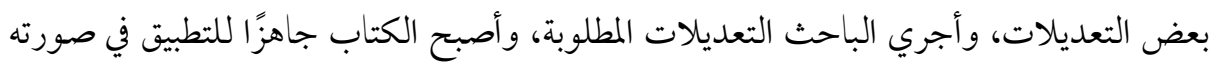

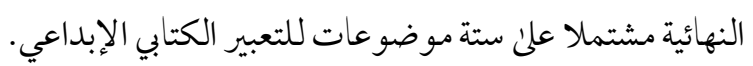
3 - دليل المعلم في ضوء الإستراتيجية المقترحة: أ - الهدف من الدليل: هدف الدليل إلى توضيح الإجراءات التدريسية وفق الإستراتيجية المقترحة؛ حتى المئى

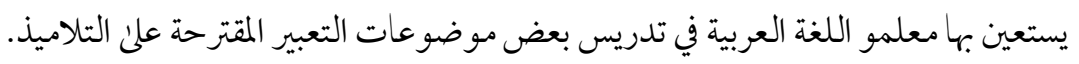

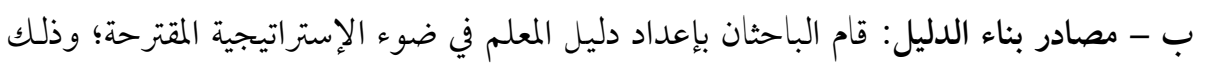

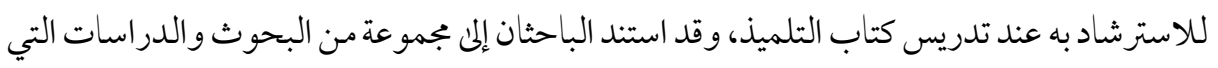

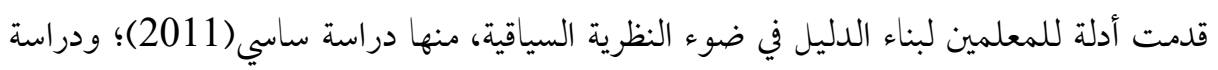
محمد(2017)، ودراسة محمود(2017)، ودراسة دميثير (2018). جـ - إعداد دليل المعلم في صورته الأولية: اشتمل الدليل في صورته وده الأولية على قسمين أساسيين هما: 1 ) - (القسم النظري، وتضمن الآتي:

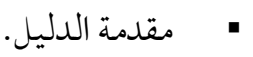

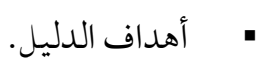

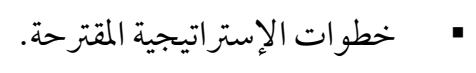
• أهداف تدريس التعبير.

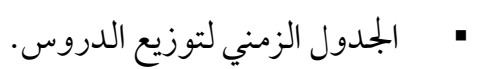

\section{http://dx.doi.org/10.29009/ijres.4.3.3}




\section{2) القسم التطبيقي، وتضمن الآتي:}

" - تحديد المهار ات المستهدف تنميتها من كل موضوع لدئ التلاميذ.

- - تحديد الأهداف الإجرائية المتوقع من التلميذ أن يكون قادرًا على تحقيقها في نهاية كل درس. " - تضمين كل موضوع بجموعة من الأنشطة التي تتيح الفرصة للتلاميذ لاستخدام المهارات الإبداعية

$$
\text { في ضوء الإستراتيجية المقترحة. }
$$

• - طريقة التدريس المتبعة، وزمن التدريس، والوسائل المستخدمة، والأنشطة والتقويم. د- عرض الدليل على المحكمين: تم عرض دليل المعلم على مجموعة من المحكمين المختصين

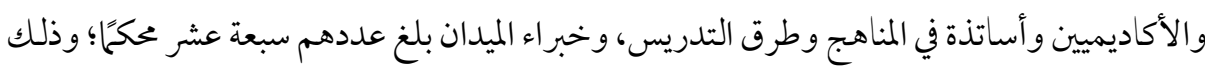
للأخذ بر أيهم فيما يتعلق بالتالي: - مدئ مناسبة الدليل لتدريس الموضوعات المقترحة. - مناسبة الخطة الزمنية لتدريس الموضوعات المقترحة. - مناسبة الأهداف العامة والإجر ائية للإستراتيجية المقترحة. - مناسبة الأنشطة المقدمة في الإستراتيجية. - مناسبة خطوات الإستراتيجية المقترحة للتدريس. هـ - الدليل في صورته النهائية: تم عرض الدليل في صورته الأولية؛ وذلك بهدف تحديد مدئ استيفاء دليل المعلم للمكونات الواجب توافرها فيه ومدئ وضوحه ومناسبته، وقد أجمع المحكمون على صلاحية دليل المعلم للتطبيق بعد إبداء آرائهم في الدليل، وخاصة في التوجيهات التي تضمنها الدليل، وأجرئ الباحثان التعديلات المطلوبة، وأصبح الدليل في صورته النهائية جاهزًا للتطبيق.

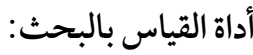
للإجابة عن السؤال الرابع من أسئلة البحث، والذي نصه: "ما فاعلية الإستراتيجية المقترحة القائمة على السياقية في تنمية مهارات التعبير الكتابي الإبداعي لدى تلاميذ الصف الأول الإعدادي الموهوبين لغويَّاب؟ 
Prof. Dr. Adbel Razek Mokhtar Mahmoud \& Eslam Gamal Mahrous Farrag

Volume (4) No. (3) 2021

تم إعداد اختبار مهارات التعبير الكتابي الإبداعي لقياس كفاءة الإستراتيجية في تنمية مهارات التعبير الكتابي الإبداعي لدئ تلاميذ الصف الأول الإعدادي الموهوبين لغويًّا، وقد مر إعداد الاختبار

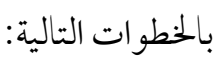
أ - تحديد المدف من الاختبار: تطلب البحث الحلالي وضع اختبار في مهارات التعبير الكتابي الإبداعي لتلاميذ الصف الأول الإعدادي الموهوبين لغويًا، وقد هدف الاختبار إلى تعرف مدئ تنمية بعض مهارات التعبير الكتابي الإبداعي المحددة بالبحث لدىن التلاميذ، من خلال التدريس بالإستراتيجية

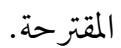
ب- مصادر بناء الاختبار: استند الباحثان إلى بموعة من البحوث والدراسات والتي تتصل بالإبداع لبناء الاختبار منها، دراسة موسى (2008)؛ محمد(2014)؛ ناصر(2017)؛ عبد العال (2018)؛ حسين(2018)؛ علي (2018). ج - وصف الاختبار: - - يقيس الاختبار ثلاث مهارات رئيسة من مهارات التعبير الكتابي الإبداعي، وهي: (الطلاقة-

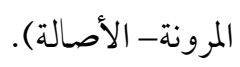

• - تتضمن مهارة الطلاقة ست مهارات فرعية، وتتضمن مهارة المرونة أربع مهارات فرعية، وتتضمن مهارة الأصالة أربع مهارات فرعية، وبذلك يكون إجمالي المهارات الكلية أربع عشرة مهارة فرعية. • - اشتمل الاختبار علن عشرين سؤالاً؛ حيث تقيس الأسئلة مهارات التعبير الكتابي الإبداعي. جدول (5) يوضح توزيع مهارات التعبير الكتابي الإبداعي في صورتها النهائية علن أسئلة الاختبار

\begin{tabular}{|c|c|c|c|c|c|}
\hline \multirow{3}{*}{ الأسئلة } & \multicolumn{3}{|c|}{ أرقام الأسئلة } & \multirow{3}{*}{ 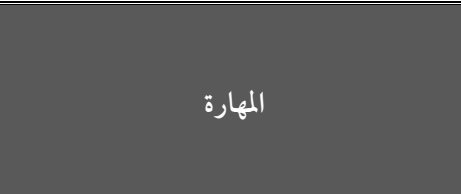 } & \multirow{3}{*}{ المهارة الرئيسة } \\
\hline & الجزء & الجزء & الجزءء & & \\
\hline & 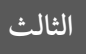 & الثاني & 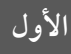 & & \\
\hline \multirow[b]{2}{*}{8} & & 8 & 6 & كتابة أكبر عددمن الأفكار المرتبطة بالموضوع. & \multirow[b]{2}{*}{ 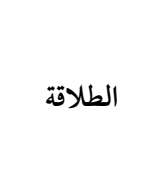 } \\
\hline & - & - & 4 & 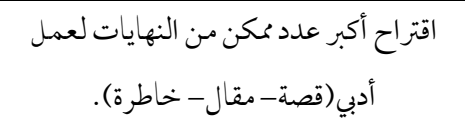 & \\
\hline
\end{tabular}




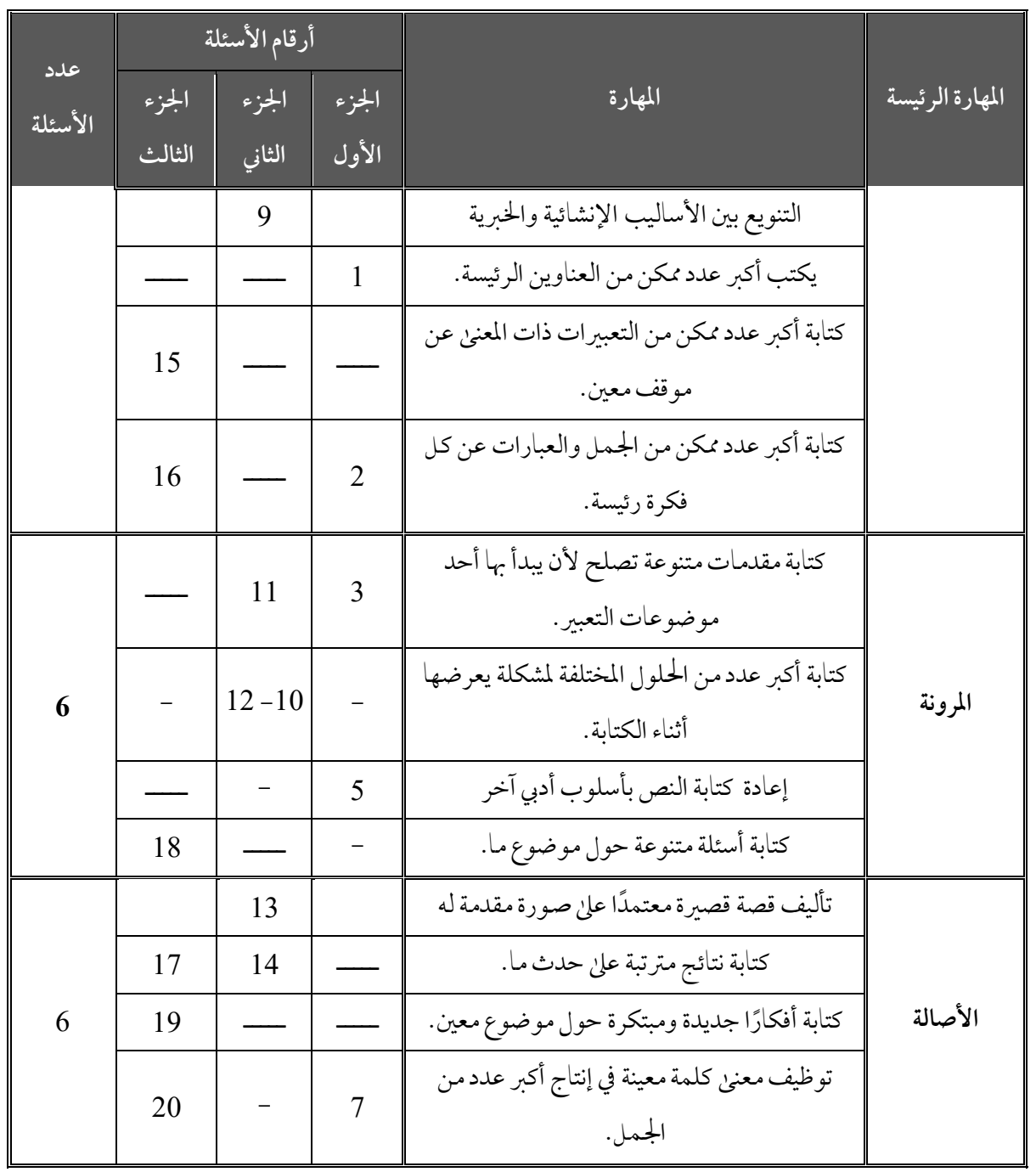

د- التجربة الاستطلاعية للاختبار: بعد التوصل للصورة النهائية للاختبار تم تطبيقه على عينة استطلاعية بلغ عددها (25) تلميذًا وتلميذة من تلاميذ الصف الأول الإعدادي الموهوبين لغويًا، بمدرسة الوعاضلة الإعدادية المشتركة التابعة لإدارة صدفا التعليمية؛ وذلك لتحديد ما يلي: - صدق الاختبار: يقصد بصدق الاختبار كفاءته في قياس ما وضع لقياسه، وقد اعتمد الباحث في تحديدصدق الاختبار علن نوعين من الصدق: 
Prof. Dr. Adbel Razek Mokhtar Mahmoud \& Eslam Gamal Mahrous Farrag

Volume (4) No. (3) 2021

- صدق المحكمين: حيث تم عرض الاختبار في صورته الأولية علن بجموعة من المحكمين المتخصصين في المناهج وطرق التدريس، بلغ عددهم 27 محكمًا. - صدق الاتساق الداخلي: حيث أمكن حساب معاملات الارتباط بين درجة الفقرات ودرجة الأبعاد الفرعية وكذلك حساب معامل الارتباط بين الأبعاد الفرعية والدرجة الكلية للاختبار. جدول(6) الاتساق الداخلي بين الفقرات والأبعاد الفرعية، ودرجة الأبعادو الدرجة الكلية لاختبار التعبير الكتابي

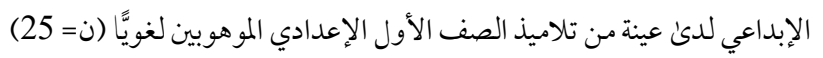

\begin{tabular}{|c|c|c|c|c|c|}
\hline \multicolumn{2}{|c|}{ الأصالة } & \multicolumn{2}{|c|}{ المرونة } & \multicolumn{2}{|c|}{ الطلاقة } \\
\hline الارتباط & الفقرة & الارتباط & الفقرة & الارتباط & الفقرة \\
\hline *** 0.745 & 7 & $* 0.741$ & 3 & $* * 0.520$ & 1 \\
\hline ***0.658 & 13 & **0.654 & 5 & $* * 0.754$ & 2 \\
\hline **** 0.695 & 14 & ***0.847 & 10 & $* * 0.732$ & 4 \\
\hline *** 0.739 & 17 & **0.812 & 11 & $* * 0.841$ & 6 \\
\hline **** 0.790 & 19 & $* 0.760$ & 12 & $* * 0.621$ & 8 \\
\hline *** 0.700 & 20 & $* 0.754$ & 18 & $* * 0.741$ & 9 \\
\hline & & & & ***6.658 & 15 \\
\hline & & & & $* * 0.741$ & 16 \\
\hline \multicolumn{2}{|c|}{ ***0.881 } & \multicolumn{2}{|c|}{ **0.841 } & \multicolumn{2}{|c|}{ ***0.749 } \\
\hline
\end{tabular}

0.01 مالة عند مستوى يتضح من خلال الجدول السابق أن معاملات الارتباط بين درجة الفقرات بالاختبار تعبر عن اتساق داخلي جيد للاختبار؛ مما يدل على صلاحية الاختبار للتطبيق على عينة البحث. - حساب معامل ثبات الاختبار : تم حساب ثبات الاختبار بطريقتين، هما:

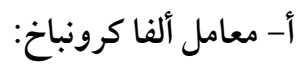

حيث تم حساب ثبات الاختبار باستخدام معامل ألفاكرونباخ؛ وذلك بتطبيقه علن مجموعة من تلاميذ الصف الأول الإعدادي الموهوبين لغويًّا بلغ عددها (25) تلميذًا وتلميذة. 
جدول (7) معامل ثبات ألفا كرونباخ لاختبار التعبير الكتابي الإبداعي لتلاميذ الصف الأول الإعدادي الموهوبين لغويًّا

\begin{tabular}{|c|c|}
\hline معامل ألفا كرونباخ ن(25) & المتغيرات \\
\hline 0.738 & مهار ات الطلاقة \\
\hline 0.831 & 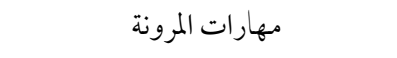 \\
\hline 0.741 & مهار ات الأصالة ل \\
\hline 0.755 & الدرجة الكلية للتعبير الكتابي الإبداعي \\
\hline
\end{tabular}

يتضح من خلال الجمدول السابق أن معاملات ألفا كرونباخ بلغت (0.738، 0.831،

0.741، 0.755) لمتغيرات مهارات الطلاقة، والمرونة، والأصالة، والدرجة الكلية للتعبير الكتابي الإبداعي، وهي قيم تعبر عن مستوى ثبات جيد للاختبار؛ مما يجعل الباحثين مطمئنين لاستخدام الاختبار بالبحث الحالي.

ب- طريقة التجزئة النصفية: حيث تم حساب ثبات الاختبار باستخدام طريقة التجزئة النصفية؛ وذلك بتطبيقه على مجموعة من تلاميذ الصف الأول الإعدادي الموهوبين لغويَّا بلغ عددهم (25) تلميذًا وتلميذة. جدول (8) ثبات التجزئة النصفية لاختبار التعبير الكتابي الإبداعي لتلاميذ الصف الأول الإعدادي الموهوبين لغويًّا (ن= 25)

\begin{tabular}{|c|c|c|c|}
\hline \multicolumn{2}{|c|}{ ثبات التجزئة بعد تصحيح أثر طول } & \multirow[t]{2}{*}{ معامل الارتباط } & \multirow[t]{2}{*}{ المتغيرات } \\
\hline 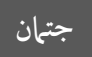 & سبرمان - براون & & \\
\hline 0.881 & 0.884 & 0.791 & مهارات الطلاقة \\
\hline 0.839 & 0.840 & 0.724 & 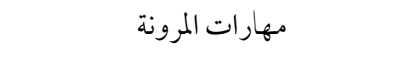 \\
\hline 0.876 & 0.881 & 0.788 & 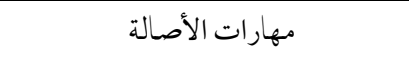 \\
\hline 0.729 & 0.745 & 0.594 & الدرجة الكلية للتعبير الكتابي الإبداعي \\
\hline
\end{tabular}

يتضح من خلال الجمدول السابت أن معاملات ثبات التجزئة النصفية بلغت (0.884، 0.840، 0.881، 0.745)، بمعادلة سبيرمان براون، وكما بلغ ثبات التجزئة النصفية (0.881، 0.839، 0.876، 0.729)، بمعادلة جتمان لمتغيرات مهارات الطلاقة والمرونة والأصالة والدرجة 
Prof. Dr. Adbel Razek Mokhtar Mahmoud \& Eslam Gamal Mahrous Farrag

Volume (4) No. (3) 2021

الكلية للتعبير الكتابي الإبداعي علن التوالي، وهي قيم تعبر عن مستوئ ثبات جيدللاختبار بما يدل علن ثبات الاختبار وصلاحية للتطبيق بالبحث. - حساب زمن الاختبار: تم تحديد زمن الاختبار عن طريق تحديد الزمن الذي استغرقه أول تلميذ في

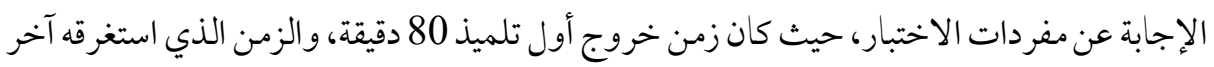

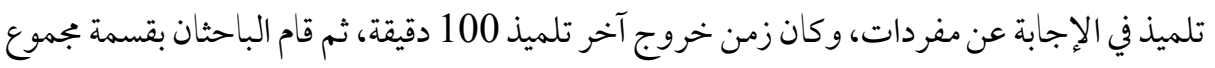

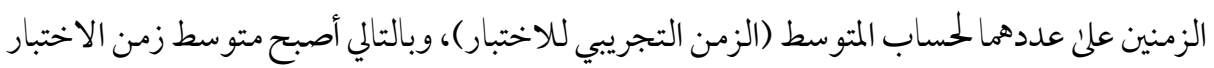

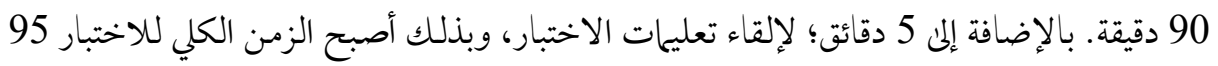

$$
\text { زمن الاختبار= }
$$

ز - وضع نظام تقدير الدرجات وطريقة التصحيح:

تم الاعتلاد في تحديد درجة كل مفردة علن بطاقة تقدير متدرجة، تكونت من أربعة خيارات:

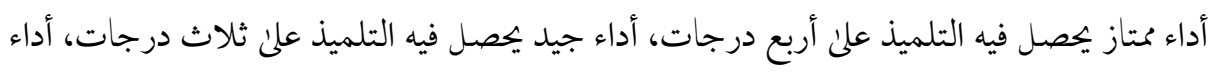

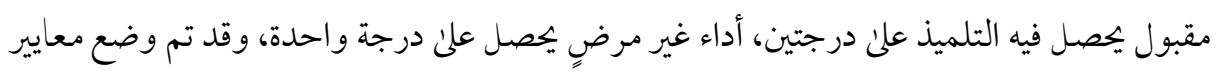
ل الكل درجة من الدرجات لكل مفردة.

\begin{tabular}{|c|c|c|c|}
\hline أداء غير مرض & أداء مقبول & أداء جيد & أداء كتاز \\
\hline & 2 & 3 & 4 \\
\hline
\end{tabular}

جدول(9) طريقة تصحيح اختبار التعبير الكتابي الإبداعي

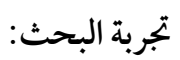

تم تطبيق تجربة البحث بمدرسة الوعاضلة الإعدادية المشتركة التابعة لإدارة صدفا التعليمية علن تلاميذ الصف الأول الإعدادي الموهوبين لغويًّ عينة البحث.

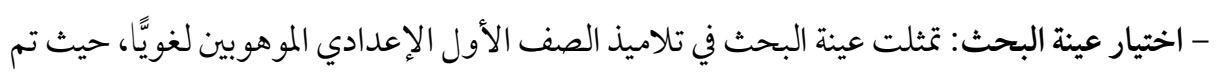

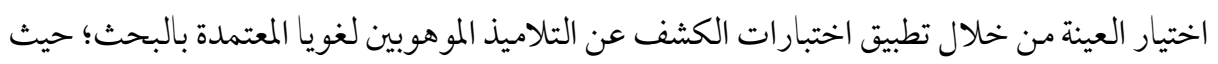


تم تطبيق اختباري الذكاء العالي والتفكير الابتكاري علن جميع تلاميذ الصف الأول الإعدادي بمدرسة الوعاضلة الإعدادية المشتركة، البالغ عددهم (150) تلميذًا وتلميذة، وأسفرت النتائج عن أن (62) تلميذًا وتلميذة موهوبون لغويًا، تم تقسيمهم إلى بجموعة استطلاعية قدرها (25) تلميذًا، وبجموعة تجريبية أساسية للدراسة بلغ عددها (37) تلميذًا وتلميذة. - التطبيق القبلي لأدوات الدراسة:

تم تطبيق اختبار التعبير الكتابي الإبداعي علن مجموعة البحث من تلاميذ الصف الأول

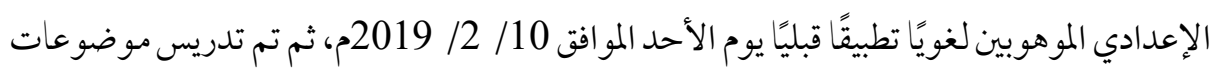
التعبير باستخدام الإستراتيجية المقترحة لتنمية مهارات التعبير الكتابي الإبداعي، وذلك خلال الفصل

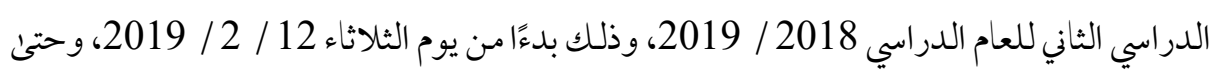
الأربعاء المو افق 27 / 2 / 2019م علن مدار أسبوعين بو اقع ثلاثة أيام في الأسبوع، وحصتين في اليوم.

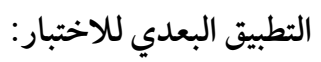
بعد الانتهاء من تدريس الموضوعات باستخدام الإستراتيجية المقترحة تم تطبيق اختبار التعبير الكتابي الإبداعي على التلاميذ تطبيقًا بعديًا يوم الخميس 28/ 2/ 2019م؛ حتى تتم المقارنة بين نتائج التلاميذ في التطبيقين القبلي والبعدي، باستخدام البرنامج الإحصائي (SPSS)؛ وذلك للتأكد من فاعلية الإستراتيجية المقترحة في تنمية مهارات التعبير الكتابي لدىن تلاميذ الصف الأول الإعدادي الموهوبين لغويًّا.

نتائج البحث في اختبار التعبير الكتابي الإبداعي لتلاميذ الصف الأول الإعدادي الموهوبين لغويًّا. يوضح الجدول التالي المتوسط الحسابي والانحر اف المعياري وقيمة "ت" ودلالتها الإحصائية لدرجات أفر اد بجموعة البحث في التطبيقين القبلي والبعدي في اختبار مهارات التعبير الكتابي الإبداعي ككل لدئ تلاميذ الصف الأول الإعدادي الموهوبين لغويَّا. 
Prof. Dr. Adbel Razek Mokhtar Mahmoud \& Eslam Gamal Mahrous Farrag

Volume (4) No. (3) 2021

جدول (10) المتوسط الحسابي والانحراف المعياري وقيمة "ت" ودلالتها لدرجات مجموعة البحث في التطبيقين القبلي والبعدي

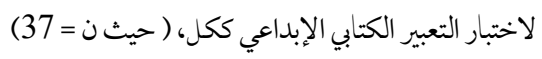

\begin{tabular}{|c|c|c|c|c|c|c|}
\hline \multirow{2}{*}{ مستوى الدلالة } & \multirow{2}{*}{ 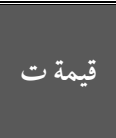 } & \multicolumn{2}{|c|}{ القياس البعدي } & \multicolumn{2}{|c|}{ القياس القبلي } & \multirow{2}{*}{ المتغيرات } \\
\hline & & $\varepsilon$ & $p$ & $\varepsilon$ & $p$ & \\
\hline 0.01 & 33.847 & 1.94 & 68.54 & 2.74 & 49.86 & الدرجة الكلية للتعبير الإبداعي \\
\hline
\end{tabular}

$$
\text { حيث إن، (ن =عدد التلاميذ، م = المتوسط الحسابي، ع = الانحر اف المعيار) }
$$

يتضح من خلال الجمدول السابق أن هناك فرقًا بين متوسطي مجموع درجات بجموعة البحث في

اختبار التعبير الكتبي الإبداعي ككل بين التطبيقين القبلي والبعدي وذلك لصالح القياس البعدي؛ حيث بلغ المتوسط في التطبيق القبلي(49.86)، لاختبار التعبير الكتابي الإبداعي ككل، بينما بلغ متوسط التطبيق البعدي(68.54)، وكان متوسط الفرق بينها) (18.68)، لصالح التطبيق البعدي؛ مما يؤكد تحسنًا واضحًا في الجانب الأدائي لمهارات التعبير الإبداعي ككل لدئ تلاميذ الصف الأول الإعدادي

$$
\text { الموهوبين لغويَّا بعد تطبيق الإستراتيجية المقترحة. }
$$

- - وبالنسبة لتفصيل المهارات الفرعية التي تكون منها اختبار التعبير الكتابي الإبداعي، وبيان الفروق بين متوسطات درجات المجموعة قبل تطبيق الإستراتيجية وبعده، فيمكن توضيح ذلك من خلال الجدول التالي الذي يوضح المتوسط الحسابي، والانحر اف المعياري، ودلالتها لدرجات أفراد المجموعة في التطبيقين القبلي والبعدي في المهارات الفرعية للتعبير الكتابي الإبداعي مفصلة، حيث (ن=37).

\begin{tabular}{|c|c|c|c|c|c|c|c|c|c|}
\hline \multirow[b]{2}{*}{$\begin{array}{l}3 \\
5 \\
1 \\
\frac{1}{3} \\
\frac{1}{3}\end{array}$} & \multirow{2}{*}{$\frac{3}{3}$} & \multirow[b]{2}{*}{ 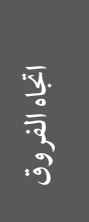 } & \multirow[b]{2}{*}{$\begin{array}{l}3 \\
3 \\
\text { y } \\
\overline{3} \\
\text { ไ. }\end{array}$} & \multirow[b]{2}{*}{$\begin{array}{l}3 \\
3 \\
3 \\
3\end{array}$} & \multicolumn{2}{|c|}{ القياس البعدي } & \multicolumn{2}{|c|}{ القياس القبلي } & \multirow[b]{2}{*}{ المتغيرات } \\
\hline & & & & & $\varepsilon$ & $p$ & $\varepsilon$ & $p$ & \\
\hline كبير & 0.92 & البعدي & 0.01 & 19.868 & 1.24 & $\begin{array}{c}27.9 \\
4\end{array}$ & 207 & $\begin{array}{c}19.5 \\
9\end{array}$ & الطلاقة \\
\hline
\end{tabular}
جدول (11) المتوسط الحسابي والانحر اف المعياري وقيمة "ت" ودلالتها لدرجات مجموعة البحث في التطبيقين القبلي والبعدي

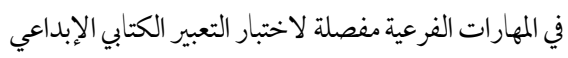

http://dx.doi.org/10.29009/ijres.4.3.3 
أ.د. عبدالرازق غختار محمود \& إسلام جمال محروص فراج المجلد (4) العدد (3) 2021م

\begin{tabular}{|c|c|c|c|c|c|c|c|c|c|}
\hline \multirow{2}{*}{$\frac{3}{3}$} & \multirow{2}{*}{$\frac{1}{3}$} & \multirow{2}{*}{ 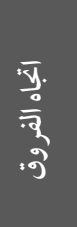 } & \multirow{2}{*}{$\begin{array}{l}3 \\
3 \\
\overline{3} \\
\overline{3} \\
\overline{3}\end{array}$} & \multirow[b]{2}{*}{ "3: } & \multicolumn{2}{|c|}{ القياس البعدي } & \multicolumn{2}{|c|}{ القياس القبلي } & \multirow[b]{2}{*}{ المتغيرات } \\
\hline & & & & & $\varepsilon$ & $\rho$ & $\varepsilon$ & $\rho$ & \\
\hline كبير & 0.90 & البعدي & 0.01 & 17.414 & 1.01 & 20.43 & 1.52 & 15.19 & مهارات المرونة \\
\hline كبير & 0.93 & البعدي & 0.01 & 22.134 & 1.14 & 20.62 & 1.01 & 15.08 & مهارات الأصلة \\
\hline كبير & 0.97 & البعدي & 0.01 & 33.847 & 1.94 & 68.54 & 2.74 & 49.86 & للتعبير الإبداعي \\
\hline
\end{tabular}

• - بالنسبة لمهارات التعبير الكتابي الإبداعي في بجال (الطلاقة):

بلغ متوسط درجات بجموعة البحث في التطبيق القبلي لها (19.59)، في حين بلغ متوسط درجات المجموعة في التطبيق البعدي للمهارات نفسها (27.49)، وكان متوسط الفرق بينها (7.9). • - بالنسبة لمهارات التعبير الكتابي الإبداعي في بجال (المرونة): بلغ متوسط درجات بجموعة البحث في التطبيق القبلي لها (15.19)، في حين بلغ متوسط درجات المجموعة في التطبيق البعدي للمهارات نفسها (20.43)، وكان متوسط الفرق بينها (5.24). • - بالنسبة لمهارات التعبير الكتابي الإبداعي في مجال (الأصالة): بلغ متوسط درجات مجموعة البحث في التطبيق القبلي ها (15.08)، في حين بلغ متوسط درجات المجموعة في التطبيق البعدي للمهارات نفسها (20.62)، وكان متوسط الفرق بينها (5.54). وقد تم حساب قيمة حجم الأثر للإستراتيجية المقترحة القائمة علن السياقية لتنمية مهارات التعبير الكتابي الإبداعي، والجددول التالي يوضح ذلك جدول (12) ويلاحظ من العرض السابق أن التحسن الأكبر لدئ التلاميذ جاء في مهارة الأصالة، ويمكن إرجاع ذلك إلى الإجراءات التدريسية التي تم اتباعها في الإستراتيجية المقترحة، والأنشطة التعليمية

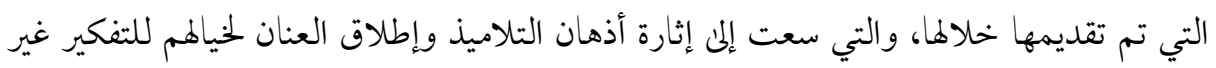


المألوف والإبداع فيما يعرض عليهم من موضوعات، كما أن بيئة التعلم التي تم تهيئتها لتطبيق الإستراتيجية من خلال استخدام مصادر التعلم المتنوعة المتاحة كالبحث علن الإنترنت والفيديوهات التعليمية، والعروض التقديمية، والأنشطة المتعددة، كل ذلك ساعد التلاميذ علئ استكشاف المعلومات والإبداع و التفكير.

جدول(12) قيمة حجم الأثر للإستراتيجية المقترحة القائمة علن السياقية لتنمية مهارات التعبير الكتابي الإبداعي لدئ تلاميذ الصف الأول الإعدادي الموهويين لغويًّا

\begin{tabular}{|c|c|c|c|c|c|}
\hline \multirow{2}{*}{ مستوى حجم الأثر } & \multicolumn{2}{|c|}{ القياس البعدي } & \multicolumn{2}{|c|}{ القياس القبلي } & \multirow{2}{*}{ 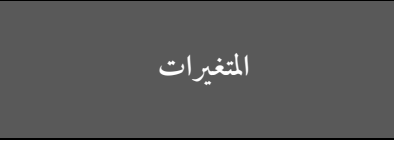 } \\
\hline & $\varepsilon$ & p & $\varepsilon$ & p & \\
\hline كبير & 1.94 & 68.54 & 2.74 & 49.86 & الدرجة الكلية للتعبير الكتابي الإبداعي \\
\hline
\end{tabular}

يتضح من خلال الجدول السابق أن قيمة حجم الأثر للإستراتيجية المقترحة فيها يتعلق بمهارات التعبير الكتابي الإبداعي كبيرة، حيث بلغت قيمة حجم الأثر (0.97)، مما يدل علن أن للإستراتيجية المقترحة القائمة على السياقية أثرًا كبيرًا في تنمية مهارات التعبير الكتبابي الإبداعي (الطلاقة - المرونة - الأصالة)، وهذا الأثر يعد دليلًا على فاعلية الإستراتيجية المقترحة.

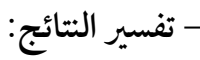
- ساعدت الإستراتيجية المقترحة علن خلق نوع من العمل الجماعي الذي يتسم بالتعاون، وإيهابية التلاميذ، وإيجاد مواقف تعليمية تشجع علن الإبداع، كما أن حسن استخدام الألفاظ المناسبة للمقام، أدئ إلى اكتساب التلاميذ المفردات التي تساعدهم علن الكتابة والإبداع. - استخدام الإستراتيجية المقترحة الأنشطة التي تتيح للتلاميذ مسافة للانطلاق بقدراتهم وطاقاتهم الفكرية، واستثارة حواسهم، وذلك من خلال الأنشطة المقدمة لهم في كل درس؛ حيث تترك لفم حرية التعبير وإخراج ما لديهم من أفكار إبداعية. - تخطيط الدروس بشكل تتكامل فيه مهارات التعبير الكتابي الإبداعي وفقًا للإستراتيجية المقترحة؛ أدئ إلى سهولة الانتقال من موضوع إلى آخر في موضوعات المحتوئ المقدم للتلاميذ. 
- تعدد الوسائل التعليمية في تنفيذ الدروس، مثل: العروض التقديمية، والداتا شو؛ لعرض القصص التي تنمي القدرة علن التفكير والإبداع، واللوحات التعليمية، كان ها دور واضح في إثارة انتباه التلاميذ وتشويقهم في أثناء تدريس موضوعات البحث، وكذلك عرض المحتوئ التعليمي علن التلاميذ ومناقشتهم فيه وما تضمنه من معان وأفكار. وتتفق نتائج البحث الحلالي مع نتائج دراسة كل من، رشيد(2010)؛ ودراسة محمود(2007)؛ ودراسة محمد (2014)؛ ودراسة عبد العال (2018)؛ ودراسة حسين(2018)، ودراسة علي(2018). • - التوصيات والمقترحات 1 - توصيات البحث: في ضوء ما تم التوصل إليه من نتائج بالبحث، يوصى البحث بالآتي:

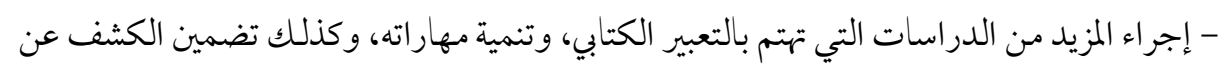

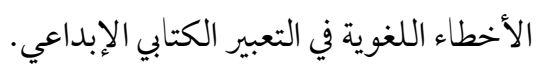
- توظيف الإستراتيجيات الحديثة في تدريس التعبير، ورفع كفاءة المعلمين من خلال عقد دورات تدريبية دورية لهم حول كيفية استخدام هذه الإستراتيجيات. - الاهتمام بمجالات التعبير الكتابي الإبداعي والتي تهم التلاميذو وتصل بحياتهم، وتقديمها لهم. - تضمين كتب اللغة العربية بعض موضوعات التعبير الكتابي. - إعطاء حصة التعبير الاهتمام الكافي من قبل وزارة التربية والتعليم، وبيان أهمية التعبير في حياتهم. - ترك الحرية للتلاميذ لاختيار الموضوعات التي تتناسب مع ميولمم ورغباتهم تحت إشراف معلميهم، وتقديم التوجيه إذا تطلب الأمر. - عقد دورات خاصة للمعلمين لتعريفهم بالإستراتيجيات والأساليب الحديثة لتدريس التعبير. - تشجيع التلاميذ علن الكتابة الشخصية التي يعبرون بها عن آرائهم، وخبراتهم، ومشاعرهم. 2 - مقترحات البحث. - فاعلية برنامج تعليمي في تدريس القراءة قائم على السياقية لتنمية بعض مهارات التعبير الكتابي لدنى تلاميذ المرحلة الإعدادية. 
- - فاعلية استخدام النظرية السياقية في تنمية مهارات القصة والمقال الأدبي لدني تلاميذ المرحلة الإعدادية. - فاعلية استخدام إستراتيجية مقترحة قائمة علن السياقية في تنمية مهارات الكتابة الإبداعية وفهم المقروء لدئ طلاب المرحلة الثانوية. - فاعلية إستراتيجية مقترحة قائمة علئ السياقية لتنمية مهارات التذوق الأدبي والثروة اللغوية لدني طلاب المرحلة الثانوية. - فاعلية استخدام نموذج تدريسي قائم علن السياقية لتنمية مهارات الكتابة الإقناعية لدى تلاميذ المرحلة الإعدادية. 


\section{المراجع}

1. أبو جادو، صالح؛ نوفل، محمد بكر (2007) . تعليم التفكير النظرية والتطبيق، الأردن، دار

$$
\text { المسيرة. }
$$

2. أبو جبين، عطا حمدا (2011). إستراتيجيات ومهارات التفكير الإبداعي في اللغة العربية

$$
\text { تطبيقات عملية، القاهرة، دار الفلاح. }
$$

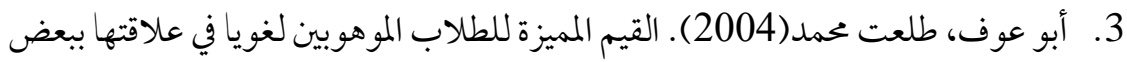

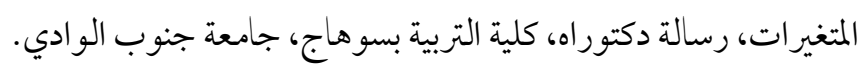

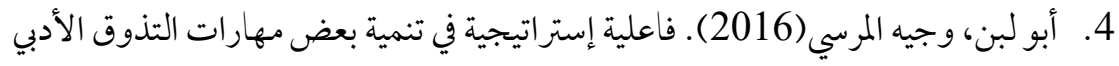
والتعبير الكتابي الإبداعي لدئ طلاب الصف الأول الثانوي، دراسات عربية في التربية

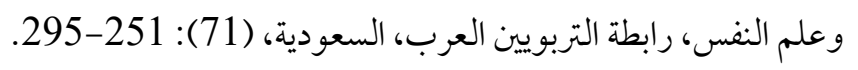

5. أمد، سوسن رضوان(2017) . إستراتيجية قائمة علن مدخل عمليات الكتابة لتنمية مهارات

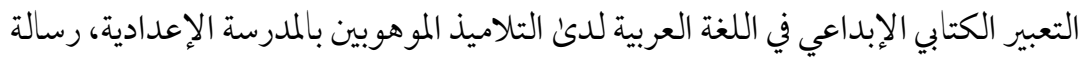

$$
\text { ماجستير غير منشورة، كلية الدراسات العليا للتربية، جامعة القاهرة. }
$$

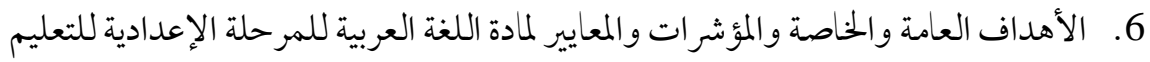

$$
\text { العام، 2008، 2009م. }
$$

7. جاب الله، علي سعد(2016). فاعلية إستراتيجية إلماعات السياق في تنمية مهارات القراءة

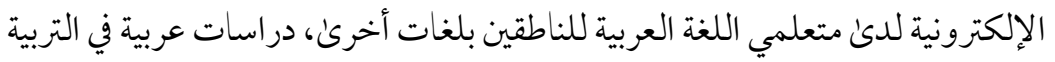

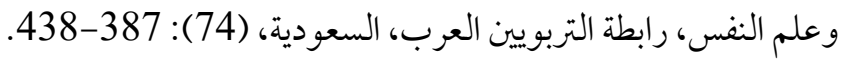

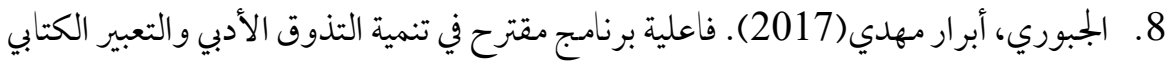
الإبداعي لدئ طلاب المرحلة الثانوية بجمهورية العراق، مجلة القراءة والمعرفة، كلية التربية، جامعة عين شمس، مصر،(185): 85-115. 
9. جراون، فتحلى عبدالرحمن(2002). أساليب الكشف عن الموهوبين والمتفوقين ورعايتهم، عمان، الأردن، دار الفكر العربي.

10. جروان، فتحي عبد الرحمن(2007) . تعليم التفكير مفاهيم وتطبيقات، القاهرة، دار الفكر العربي.

11. حبيب، مجدي عبد الكريم(2000). التقويم والقياس في التربية وعلم النفس، المجلد الثاني، القاهرة، مكتبة النهضة المصرية.

12. حسام عبد علي الجمل (2014). الدلالة السياقية للحذف في النص النحوي، مجلة مركز بابل للدراسات الإنسانية، جامعة بابل، العراق، 4(1): 319-352.

13. حسين، شفاء محمد(2018). فاعلية برنامج قائم علن الخر ائط الذهنية الرقمية لتنمية بعض مهارات القر اءة والكتابة الإبداعية لدئ طلاب شعبة اللغة العربية بكلية التربية بقنا، رسالة دكتور غيه منشورة، كلية التربية بقنا، جامعة جنوب الو ادي.

14. حماد، خليل عبد الفتاح؛ نصار، خليل محمود(2002). فن التعبير الوظيفي، غزة، فلسطين، مكتبة منصور.

15. الخطيب، عامر يوسف(2003). أدوار المعلم في التربية الإبداعية بمدرسة الموهوبين، الأردن، عمان، دار الفكر للنشر و الطباعة والتوزيع. 16 داود، محمد محمد (2001). "العربية وعلم اللغة الحديث"، القاهرة، دار غريب. 17 ـ دميثير، سلطان( 2018 ). برنامج إثرائي قائم علن السياقية لتنمية التذوق الأدبي وأثر ذلك علن التعبير الكتابي لدى تلاميذ المرحلة المتوسطة بالكويت، رسالة دكتوراه، كلية الدراسات

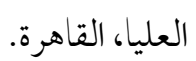

18 ـرشيد، محمد عوض (2010). فاعلية مدخل عمليات الكتابة في تنمية بعض مهارات التعبير الكتابي الإبداعي لدن طلاب الصف الثاني متوسط بالمدينة المنورة، رسالة ماجستير غير منشورة، كلية التربية، جامعة طيبة، السعودية. 
19 ـ الزهر اني، مرضي بن غرم الله(2008) . مستوكن إسهام بر امج الإعداد التربوي بجامعة أم

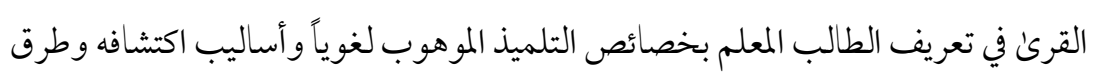
رعايته، بجلة القراءة والمعرفة- كلية التربية، جامعة عين شمس، مصر - أغسطس، (81): $92-14$

20. ساسي، عبد الكريم(2011). السياق اللغوي وأثثه في تعليمية اللغة العربية لدئ الطفل في ضوء المقاربة بالكفاءات(السنة الخامسة من التعليم الابتدائي نموذجًا)، رسالة ماجستير غير منشورة، جامعة الحاج لخضر (باتنة)، الجزائر.

21. السايج، تهاويل عطا الله (2014). أثر إستراتيجيتي الألعاب اللغوية وسرد القصة في تحسين مهارات الكتابة الإبداعية لدىٔ طالبات الصف التاسع الأساسي في الأردن، رسالة دكتوراه، كلية التربية، جامعة اليرموك، الأردن.

22. سليمان، محمود جلال الدين (2015). علم اللغة الاجتماعي وتطبيقاته في تعليم العربية،

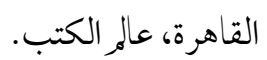

23. السمان، مروان أحمد(2018). نموذج تدريسي قائم علن النظرية السياقية لتنمية مهارات القراءة التفسيرية والقراءة النقدية لدىن دارسي اللغة العربية الناطقين بغيرها. دراسات في المناهج

$$
\text { وطرق التدريس. كلية التربية، جامعة عين شمس، مصر. (230): 16-65. }
$$

24. سيد، علي شياء(2018) . تنمية مهارات التعبير الكتابي الإبداعي في ضوء إستراتيجية التخيل لدئ طلاب المرحلة الثانوية، رسالة ماجستير غير منشورة، كلية التربية، جامعة عين شمس. 25. شحاتة، محمد ثروت(2016) . فاعلية برنامج مقترح قائم علن قصص الخيال العلمي في تنمية

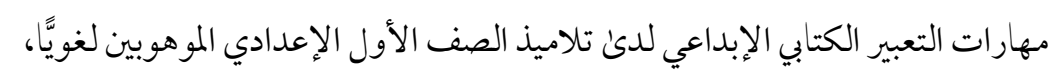
رسالة دكتوراه، كلية التربية، جامعة المنصورة.

26. الشـربيي، زكريـا أحمــ؛ صـادق، يسـرية(2002). أطفــال عنـد القمة (الموهبة والتفوق العقلي

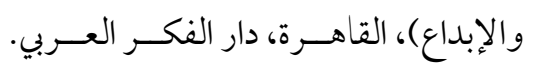


27.صادق، فاروق(2001) . نظرة مستقبلية لتربية وتعليم ذوي الاحتياجات الخاصة في القرن

$$
\text { الحادي }
$$

والعشرين، القاهرة، وزارة التربية والتعليم، المؤتمر القومي للموهوبين، أبريل: 2- 28.

28. عاشور، راتب قاسم؛ مقدادي، محمد فخري(2005). المهارات القرائية والكتابية، طرائق

$$
\text { تدريسها وإستراتيجياتها، الأردن، دار المسيرة. }
$$

29. عاصي، عماد محمد(2012). أثث استخدام مواقع الإنترنت الثقافية على التعبير الكتابي الإبداعي

لدئ طلاب الصف العاشر، رسالة ماجستير غير منشورة، كلية التربية، الجامعة الإسلامية بغزة، فلسطين.

30. عباس، سعاد عبد الكريم(2004). طرائق تدريس الأدب و البلاغة والتعبير بين التنظير

$$
\text { و التطبيق، الأردن، دار الشروق. }
$$

31. عبد الباري، عبد التواب محمد(2016). برنامج قائم على الخر ائط الذهنية لتنمية مهارات التعبير الكتابي الإبداعي لدى تلاميذ المرحلة الإعدادية، رسالة ماجستير غير منشورة، كلية

$$
\text { التربية، جامعة أسيوط. }
$$

32.عبد الباري، ماهر شعبان(2010). الكتابة الوظيفية والإبداعية، الأردن، دار المسيرة.

$$
\text { 33.عبد الباري، ماهر شعبان(2011). تعليم المفردات اللغوية، الأردن، دار المسيرة. }
$$

34. عبد الجو اد، إياد إبر اهيم(2001) . برنامج مقترح لتنمية المهارات الأساسية للتعبير الكتابي الإبداعي لدئ طالبات الصف الحادي عشر بمحافظة غزة، رسالة ماجستير، كلية التربية،

$$
\text { جامعة عين شمس. }
$$

35.عبد العال، أسماء حسن(2018) . فاعلية استخدام التخيل الموجه في تنمية مهارات الكتابة الإبداعية لدى تلاميذ الصف الثاني الإعدادي، رسالة ماجستير غير منشورة، كلية التربية،

\section{جامعة المنيا.}

\section{http://dx.doi.org/10.29009/ijres.4.3.3}


36. عبد القادر، عبد اللطيف(2002). فعالية برنامج لعلاج صعوبات الفهم القرائي لدئ تلاميذ الصف الر ابع الابتدائي في ضوء نظرية إلماعات السياق لستيرنبرج، دراسات في المناهج وطرق التدريس، الجمعية المصرية للمناهج وطرق التدريس، كلية التربية، جامعة عين

$$
\text { شمس، مصر، (79): 146-166. }
$$

37. عبد الله، هاني(2010). فعالية إستراتيجية قائمة على نظرية إلماعات السياق في تنمية الثروة اللغوية وبعض مهارات الفهم القرائي لدىن تلاميذ الصف الخامس الابتدائي، بجلة كلية

$$
\text { التربية بالمنصورة، مصر، (73)، ج 2: } 194 \text { - } 225 .
$$

38. عصر، محمد طه(2000) . سيكولوجية الموهبة الأدبية والطفولة، القاهرة، عالْ الكتب. 39. عطية، جمال سليمان؛ حافظ، وحيد السيد(2006). فعالية برنامج قائم علن التعلم المنظم ذاتيًا في تنمية مهارات الكتابة الإبداعية لدئ طلاب المرحلة الثانوية، مجلة كلية التربية ببنها،

$$
\text { مصر، } 16 \text { (68): 5-37-37. }
$$

40. عطية، محسن علي(2007). تدريس اللغة العربية في ضوء الكفايات الأدائية، عمان، دار

$$
\text { المناهج }
$$

41. فتح الباب، أحمدصلاح عبد الحميد(2016) . برنامج قائم على نظرية الذكاء الناجح لتنمية مهارات القراءة والكتابة الإبداعية لدئ طلاب المرحلة الثانوي، رسالة دكتوراه، كلية

$$
\text { التربية، جامعة عين شمس. }
$$

42. فرج، أحمد السيد(2020). فاعلية استخدام المدخل التكاملي الوظيفي في تنمية مهارات الإبداع اللغوي لدئ تلاميذ المرحلة الابتدائية، رسالة ماجستير، كلية التربية، جامعة المنصورة. 43. فندريس، جوزيف(2014). اللغة، ترجمة عبد الحميد الدواخلي ومحمد القصاص، القاهرة، الهيئة العامة لشئون المطابع الأميرية. 44. قاسم، ححمد جابر (2005) . معايير التفوق اللغوئ للمعلم والمتعلم، الإمارات العربية المتحدة، دبئ، دار القلم. 
45. القريطي، عبد المطلب أمين(2005). الموهوبون و المتفوقون خصائصهم واكتشافهم ورعايتهم،

$$
\text { القاهرة، دار الفكر العربي. }
$$

46. قطناني، محمد حسين؛ مريزيق، هشام يعقوب(2012) . تربية الموهوبين وتنميتهم، عحان، دار

$$
\text { المسيرة للنشر والتوزيع والطباعة. }
$$

47. كنوش، عو اطف مصطفى(2007). الدلالة السياقية عند اللغويين، لندن، دار السياب للطباعة

$$
\text { و النشر. }
$$

48. محمد، أسماء عبد المنعم (2020). استخدام إستراتيجية سكامبر في تنمية مهارات الإبداع اللغوي في اللغة العربية لتلاميذ الصف الأول الإعدادي، رسالة ماجستير، كلية التربية،

$$
\text { جامعة دمياط. }
$$

49. محمد، رجب عثمان(2003). مفهوم السياق و أنواع بجالاته وأثره في تحديد العلاقات الدلالية

$$
\text { والأسلوب، مجلة علوم اللغة، مصر، 6(4): 93- } 163 .
$$

50. محمد، عبد الرحيم فتحي (2014). برنامج باستخدام تآلف الأشتات ونموذج سكامبر لتنمية التفكير المنظومي والأداء اللغوي الإبداعي لدئ التلاميذ الموهوبين لغويًا بالمرحلة

$$
\text { الإعدادية، رسالة دكتوراه غير منشورة، كلية التربية، جامعة أسيوط. }
$$

51. محمد، هبه سعيد(2017). فاعلية برنامج قائم على النظرية السياقية ومستويات السعة العقلية في تنمية الثروة اللغوية ومهارات الكتابة الإقناعية لدئ الطلاب المعلمين شعبة اللغة

$$
\text { العربية، رسالة دكتور اه، كلية التربية بالإسماعيلية، جامعة قناة السويس. }
$$

52. حممود، عبد الرازق مختار (2007). فعالية برنامج تدريبي مقترح في إكساب معلمي اللغة

$$
\text { العربية مهارات استخدام الذكاءات المتعددة في تدريسهم وأثره علن التحصيل وتنمية }
$$

الإبداع اللغوي لدى تلاميذهم، مجلة كلية التربية، جامعة أسيوط، 23(1): 197-258.

53. حممود، عبد الرازق مختار؛ سيد، عبد الوهاب؛ أبو ناجي، شياء(2016). فاعلية نموذج تدريسي في الأدب قائم على نظرية التعلم المستند إلى الدماغ في تنمية مهارات الإبداع 
اللغوي لدئ طالبات المرحلة الثانوية. المجلة التربوية، كلية التربية، جامعة سوهاج، 44: $.334-275$

54. محمود، هيثم عمر (2017) . فاعلية إستراتيجية مقترحة لتدريس المتشابهات القر آنية قائمة علن نظرية السياق في إتقان أداء النص القرآني وتذوقه لطلاب الصف الثالث الثانوي الأزهري"، رسالة ماجستير، كلية التربية، جامعة المنيا.

55.مدكور، علي أحمد(2008). تدريس فنون اللغة العربية، القاهرة، دار الفكر العربي.

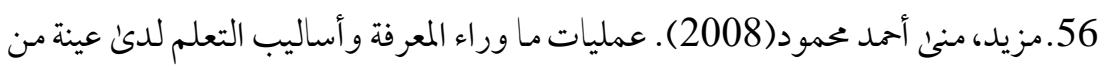
الطلاب الموهوبين لغويًا، رسالة ماجستير غير منشورة، كلية التربية، جامعة بنها. 57. مصلح، إيهان عبد الفتاح(2017). أثر تدريس النصوص الأدبية بإستراتيجية الاستقصاء والأسئلة السابرة في تنمية مهارات التعبير الإبداعي والتفكير الإيجابي لدئ طلبة المرحلة الثانوية في الأردن، رسالة دكتوراه، كلية الدراسات العليا، جامعة العلوم الإسلامية العالمية، الأردن.

58. موسئ، أميرة حسين(2008). بناء برنامج تعليمي قائم علن برنامج كورت و الكشف عن أثره

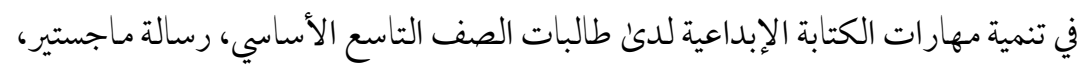
كلية الشريعة والدراسات الإسلامية، جامعة اليرموك، الأردن. 59. ناصر، أمل عبيد(2017) . فاعلية إستراتيجية قائمة علن عادات العقل في تنمية مهارات الكتابة

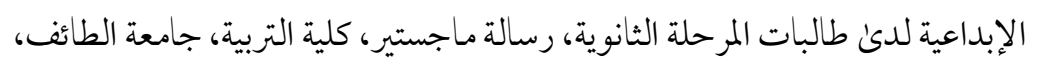
السعودية.

60. النجلاوي، صبري حافظ (2008). أثر برنامج قائم علن التنظيم الذاتي للتعلم في بعض

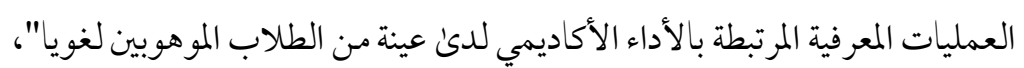
رسالة دكتور راه، كلية التربية، جامعة طنطا. 
61. الهذلي، أسماء ناصر (2016) . فاعلية برنامج قائم علن الأنشطة اللغوية الإثرائية في تنمية

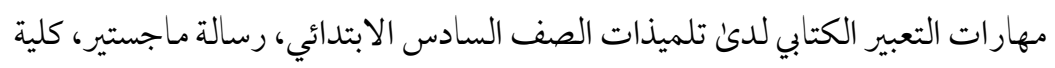
التربية، جامعة القصيم، السعودية.

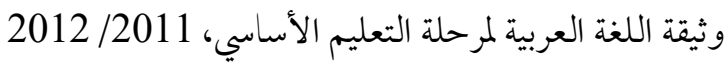




\section{References:}

- Clark، B. (1992). Growing up giftedness. New York Macmillan Publishing company.

- Context_Cues_in_Reading.

- Sarouphim، K. (2000). Internal Structure of DISCOVER A Performance Based Assessment. Journal for The Education of the Gifted، 23(3).

- Swerling ،S .1 (2006): The use of Context Cues in Reading، Available: https://www.readingrockets.org/article/use-context-cuesreading\#: :text=When\%20children\%20encounter\%20an\%20unfamiliar,sen tences $\% 20$ surrounding\%20the $\% 20$ unknown\%20word.\&text=Another\%20s ource $\% 20$ of $\% 20$ confusion $\% 20$ is,use $\% 20$ of $\% 20$ context $\% 20$ in $\% 20$ compreh ension. 